The Historical Journal, 64, 5 (2021), pp. 1198-1229 (C) The Author(s) 2021. Published by Cambridge University Press. This is an Open Access article, distributed under the terms of the Creative Commons Attribution licence (http://creativecommons.org/licenses/by/4.o/), which permits unrestricted re-use, distribution, and reproduction in any medium, provided the original work is properly cited.

doi: $10.1017 /$ Soo $18246 X_{20000667}$

\title{
VISUALIZING GERMANNESS THROUGH COSTUMES IN THE SIXTEENTH CENTURY*
}

\author{
FREDERICK G. CROFT S \\ Jesus College, Cambridge
}

\begin{abstract}
A B S T R ACT. Examining the understudied collection of costume images from Heidelberg Calvinist, lawyer, and church councillor Marcus zum Lamm's (I544-I606) 'treasury' of images, the Thesaurus Picturarum, this article intervenes in the historiography on sixteenth-century German national imaginaries, emphasizing the import of costume books and manuscript alba for national self-fashioning. By bringing late sixteenth-century ethnographic costume image collections into scholarly discourse on the variegated ways of conceiving and visualizing Germany and Germanness over the century, this article sheds new light on a complex narrative of continuity and change in the history of German nationhood and identity. Using zum Lamm's images as a case-study, this article stresses the importance of incorporating costume image collections into a nexus of patriotic genres, including works of topographical-historical, natural philosophical, ethnographic, cartographic, cosmographic, and genealogical interest. Furthermore, it calls for historians working on sixteenth-century costume books and alba to look deeper into the meanings of such images and collections in the specific contexts of their production; networks of knowledge and material exchange; and - in the German context - the political landscape of territorialization, confessionalization, and dynastic ambition in the Holy Roman Empire between the Peace of Augsburg and the Thirty Years War (I555-1618).
\end{abstract}

It was as a student at the University of Poitiers in 1564 , lodging with notaire $d u$ palais Arnault Conterrau, that the twenty-year-old Marcus zum Lamm ( $1544^{-}$ 16o6)-future jurist, Heidelberg courtier, and Calvinist church councillor

Jesus College, University of Cambridge, CB58BL fgc29@cam.ac.uk

* My thanks to Prof. Ulinka Rublack, Prof. Joachim Whaley, Dr William O'Reilly, Dr Katy Bond, Davide Martino, the staff at ULB Darmstadt, and the two anonymous reviewers, all of whom - to varying degrees - have offered me their invaluable time and expertise, helping greatly towards the completion of this article.

1198 
(Kirchenrat)-first began collecting material to furnish his unprecedented 'treasury' of images, the Thesaurus Picturarum. By the time his body was interred at Heidelberg's Peterskirche in 16o6, the Thesaurus included enough manuscript, broadside, and pamphlet material to fill thirty-nine bound volumes. Approaching topics as diverse as ornithology, Reformation theology, prodigies and monstrosities, meteorology and astrology, costumes and contemporary history, zum Lamm's Thesaurus demonstrates a remarkable use of visualities to catalogue his world and - oftentimes - project the confessional and dynastic ambitions of his overlords, the Calvinist Wittelsbach counts palatine of the Rhine.

Today, thirty-three volumes survive. Thirty-two are held at the Universitäts- und Landesbibliothek, Darmstadt, and the remaining volume at the Lipperheidesche Kostümbibliothek, Berlin. Despite its extraordinary contents, context, and historiographical utility, the Thesaurus has not been systematically researched, and is little known in its entirety among English-speaking scholars. ${ }^{1}$ This article focuses on zum Lamm's collection of costume images and what they reveal about zum Lamm's efforts to visualize Germanness. ${ }^{2}$ Whilst the ways in which Germany and the empire were constructed visually during the reign of Maximilian I are well known to modern historians, the ways and contexts in which later sixteenth-century visions of Germanness were elaborated have not received adequate consideration. Moreover, most literature on German nationalism has not considered costume books and manuscript alba. 3 Yet, I argue that these are essential apparatuses for understanding the later sixteenth century's formulations of German identity.

1 Marcus zum Lamm, Thesaurus Picturarum (c. 1564-16o6), 32 vols., ULB Darmstadt, Hs. 1971; Marcus zum Lamm, Thesaurus Picturarum (c. 1564-16o6), xxxiII, Lipperheidesche Köstumbibliotek Berlin, Aa 4; Frieder Hepp, Religion und Herrschaft in der Kurpfalz um I 6oo: Aus der Sicht des Heidelberger Kirchenrates Dr. Marcus zum Lamm (I544-I6o6) (Heidelberg, 1992), pp. 4-5o; Helga Meise, 'Höfische Repräsentation im “Thesaurus picturarum” des Marcus zum Lamm (1544-1606)', in J. D. Müller, ed., 'Aufführung' und 'Schrift' in Mittelalter und Früher Neuzeit (Stuttgart, 1996), pp. 287-306; Volker Press, Calvinismus und Territorialstaat: Regierung Zentralbehördern der Kurpfalz, I559-I6I9 (Stuttgart, 1970); Ragnar Kinzelbach and Jochen Hölzinger, Vogelbilder aus dem Thesaurus Picturarum: Herausgegeben mit Interpretation und Kommentar von Ragnar K. Kinzelbach und Jochen Hölzinger (Stuttgart, 20oo); R. Walther, 'Die Trachtenbilder im Thesaurus Picturarum des Dr. Markus zum Lamm', Zeitschrift für Waffen- und Kostümkunde, 3 (1971), pp. 77-96; Wolfgang Harms and Cornelia Kemp, Deutsche Illustrierte Flugblätter des I 6. und I 7. Jahrhunderts: Die Sammlungen Der Hessischen Landes- und Hochschulbibliothek in Darmstadt (Tübingen, 1987); Florike Egmond, Eye for detail: images of plants and animals in art and science, I5OO-I63O (London, 2017).

${ }_{2}$ These are contained in zum Lamm, Thesaurus Picturarum, IV (Palatina I), Xv (Turcica), XxxIII (Costumes), and XxxiII (Additions).

3 Helmut Walser Smith, Germany: a nation in its time: before, during, and after nationalism, I $500-$ 2000 (e-book, 2020); Thomas Lau, Teutschland: Eine Spurensuche I5oo bis I650 (Stuttgart, 2010); Alexander Schmidt, Vaterlandsliebe und Religionskonflikt: Politische Diskurse im Alten Reich (1555-I648) (Leiden, 2007); Caspar Hirschi, Wettkampf der Nationen. Konstruktionen einer deutschen Ehrgemeinschaft an der Wende vom Mittelalter zur Neuzeit (Göttingen, 2005); Joachim Whaley, Germany and the Holy Roman Empire (Oxford, 2013). 
Meanwhile, even though there has been significant work on sixteenth-century costume collections in their German, European, and 'global' contexts during the last decades, recent studies have often focused on what Giorgio Riello describes as the 'global imaginary'.4 However, many such collections also consolidated national, ethnographic self-images. 5 Although each costume collection served unique and plural functions, this article underlines how projects such as zum Lamm's must be read within the wider nexus of sixteenthcentury German topographical-historical, natural philosophical, ethnographic, cartographic, cosmographic, and genealogical genres, alongside the political context of confessionalization and territorialization.

Necessarily, this article begins with a contextual overview. The first two sections outline a genealogy of continuities, changes, and variegations in how Germany and Germanness were imagined and visualized over the sixteenth century. The second half investigates the specifics of zum Lamm's collection and his own ways of visualizing Germanness, alterity, and their imagined borders. This article argues that zum Lamm's costume images cannot be properly understood without recognizing the influence of earlier and concurrent German (and European) scholarly interests, patriotic projects, and visual practices, alongside the specific confessional and dynastic motives preoccupying Calvinist Heidelberg and the Electoral Palatinate.

Len Scales has demonstrated that a coherent German national consciousness was gradually developed from as early as the thirteenth century; qualified by a

4 Giorgo Riello, 'The world in a book: the creation of the global in sixteenth-century European costume books', Past E Present, 242 (2019), pp. 281-317; see also for costumes and the 'global imaginary': Giulia Calvi, 'Cultures of space: costume books, maps and clothing between Europe and Japan (sixteenth through nineteenth centuries)', I Tatti Studies in Italian Renaissance, 20 (2017), pp. 331-63; Valerie Traub, 'Mapping the global body', in Peter Erickson and Clark Hulse (eds.), Early modern visual culture: representation, race and empire in Renaissance (Philadelphia, PA, 200o), pp. 44-97; Ayesha Ramachandran, The worldmakers: global imagining in early modern Europe (Chicago, IL, 2015); Charlotte Colding Smith, "Depicted with extraordinary skill": Ottoman dress in sixteenth-century German printed costume books', Textile History, 44 (2013), pp. 25-5 $5^{\text {; }}$ Stephanie Leitch, 'Cosmopolitan Renaissance: prints in the age of exchange', in Daniel Savoy (ed.), The globalization of Renaissance art (Leiden, 2017), pp. 186-217.

5 For costumes and patriotism, see Ulinka Rublack, Dressing up: cultural identity in Renaissance Europe (Oxford, 2010), pp. 137-200; Bronwen Wilson, The world in Venice: print, the city, and early modern identity (Toronto, ON, 2005), pp. 70-132; Eugenia Paulicelli, 'Mapping the world: the political geography of dress in Cesare Vecellio's costume books', The Italianist, 28 (2008), pp. 24-53; Anne Rosalind Jones, 'Habits, holdings, heterologies: populations in print in a $15^{62}$ costume book', Yale French Studies, 110 (2006), pp. 92-121; for constructions of imperial identity, see Katherine Bond, 'Mapping culture in the Habsburg Empire: fashioning a costume book in the court of Charles V', Renaissance Quarterly, 7 (2018), pp. 530-79; for German patriotism and early modern ethnography, Stephanie Leitch, Mapping ethnography in early modern Germany: new worlds in print culture (Basingstoke, 2012), pp. 17-101. 
common tongue, a tradition of military triumph, and the translation of imperial rule (translatio imperii).$^{6}$ However, confidence in this late medieval conception of Germanness was perturbed by an inconvenient paradox. German claims to inherited imperial legitimacy, martial seriousness, and a natural ability to forge order from chaos, rested on the belief that they descended from their one-time Roman conquerors. For their Mediterranean rivals, this was a laughable assertion. The 'Germans [could not] choose to overlook those troublesome barbarian failings - dull-wittedness, gluttony, drunkenness, inurbanita, as well as a taste for blood - with which their neighbours charged them.'7 For the Welsch (Romance-speaking foreigners), the phrase furor Teutonicus (German fury), although stirring martial pride amongst the Germans, suggested an 'uncivilized' German thirst for blood, and was already a well-worn rhetorical cliché by the time of Petrarch. ${ }^{8}$ Furthermore, as fifteenth-century Italian humanists began recovering long forgotten classical texts, new discoveries dispelled any feasible historical claim that Germans might use to justify their Roman ancestry. In particular, the discovery of Tacitus's De origine et situ Germanorum (or Germania), first analysed in the mid-fifteenth century by Enea Silvio Piccolomini (the future Pope Pious II), forced German scholars to rewrite their historicized situation. 9

At the beginning of the sixteenth century, humanists such as Heinrich Bebel, Conrad Celtis, Ulrich von Hutten, Johannes Aventinus, Johannes Cochlaeus, and Beatus Rhenanus, urged on by their reform-minded emporer, Maximilian I (who would rename his empire the Heiliges Romisches Reich deutscher Nation in $15^{12}$ ), inverted the 'barbarian' ethnic and cultural implications suggested by the recieved Italian reading of Tacitus's Germania. ${ }^{10}$ Seen as a whole, the early German humanists (c. 1494-1520) invented a historicized and perceivable 'reality' for the Germans as an authochtonous people, whose lands - initially confined between the rivers Rhine and Danube - had been justifiably enlarged since ancient times. ${ }^{11}$ This was achieved-albeit never

6 Len Scales, 'Germen militiae: war and German identity in the later middle ages', Past $\mathcal{E}^{\circ}$ Present, 180 (2003), p. 42; Len Scales, The shaping of German identity: authority and crisis, I245-I4I4 (Cambridge, 2012); see also for late medieval 'Discourses of peace, Common Weal, and Empire', Duncan Hardy, Associative political culture in the Holy Roman Empire: Upper Germany, I346-I52I (Oxford, 2018), pp. 142-58.

7 Scales, 'Germen militiae', pp. 52-3.

8 Peter Amelung, Das Bild der Deutschen in der Literatur der italienischen Renaissance (Munich, $1964)$, pp. $35^{-73}$.

9 Christopher B. Krebs, 'Negotiatio Germaniae': Tacitus' Germania und Enea Silvio Piccolomini, Giannantonio Campano, Conrad Celtis und Heinrich Bebel (Göttingen, 2005), pp. 138-51.

${ }^{10}$ For the complex political contexts of imperial reform under Maximilian I, see Thomas Brady, German histories in the age of Reformations, I40o-I 650 (Cambridge, 2009), pp. 69-1 26; see also Heinrich Bebel's 'Oration in praise of Germany', in Gerald Strauss, Manifestations of discontent in Germany on the eve of Reformation (Bloomington, IN, 1971), pp. 70-1.

11 For sixteenth-century discourse on German expansion, see Gerald Strauss, Sixteenthcentury Germany: its topography and topographers (Madison, WI, 1959), pp. 29-44; for the construction of the 'German body', see Leitch, Mapping ethnography, pp. 37-45. 
uniformly - by tying together German history, contemporary geography, ethnography, and antiquities, a project which found its most enduring manifestation in what Gerald Strauss termed the topographical-historical genre.

Pioneering this mode of conceptualizing and visualizing Germany, Conrad Celtis upended the tradition of peregrinatio (leaving one's homeland and wandering for the love of God), propounding a new 'philosophical' state of mind; impelling Germans to travel about and contemplate their own patria. He wrote in the preface to his 1502 illustrated topographical-historical 'manifesto of German humanism', the Quatuor libri amorum (or amores):

There are plenty of people who pride themselves in having travelled to Gaul, Spain, Poland and Hungary, even the countries overseas. I, however, deem just as praiseworthy a German Philosopher who has personally observed and seen for himself the borders of his linguistic area, the various customs, laws, languages, regions, and finally the looks, the affects and the various physical properties [of the residents]. ${ }^{12}$

Collaborating with artisan-artists such as Albrecht Dürer, Celtis's Amores were authored as the prototype for a comprehensive illustrated topography of German territory, the unrealized Germania illustrata. ${ }^{13}$ Germany's boundaries were marked by the cities of Mainz, Lübeck, Krakow, and Regensburg, with Nuremberg at its centre. Celtis imagined Nuremberg not only at the centre of the German Reich, but, in the words of his friend Willibald Pirckheimer, as the 'naval of all Europe' and, correspondingly, of the whole world. ${ }^{14}$

Nevertheless, Germany (and with it, the idea-image of Germanness) would prove hard to define, its essence often elusive and its limits amorphous. For the Hamburg historian Albert Krantz $\left(145^{\mathrm{O}-1} 5^{17}\right)$, this imprecision was remedied through a bifurcate definition of Germany. The territorial Germania represented the wider, 'unstable' site of German cultural influence and imperial dominion (encompassing numerous peoples and languages) greatly expanded since ancient times, whilst Teutonia signified the 'stable' RhineDanube heartland of the German-language domain, which had remained the same since antiquity and existed despite the German Reich. ${ }^{15}$ Furthermore, an interest in the depiction and description of leading German imperial cities had stood at the practical forefront of representing and defining the German

${ }^{12}$ Conrad Celtis, Quatuor libri amorum... (Nuremburg, 1502), p. 53, translated in Jörg Robert, 'Dürer, Celtis and the birth of landscape painting from the spirit of the "Germania Illustrata", trans. Martina Stöckl, The early Dürer, ed. Daniel Hess and Thomas Eser (London, 2012), p. 67.

13 Ibid., pp. 66-7.

${ }^{14}$ Leitch, Mapping ethnography, p. 33; Schedel places a cityscape of Nuremberg at the centrefold of his 'World chronicle'; Hartmann Schedel, Liber Chronicarum (Nuremberg, 1493); see also for translatio cartographiae and German humanism, Katharina Piechoki, Cartographic humanism: the making of early modern Europe (Chicago, IL, 2019), pp. 26-50.

${ }^{15}$ Smith, Germany, p. 40; Albert Krantz, Wandalia: in qua Wandalorum populis... (Cologne, $1519)$. 
nation, cartographically and culturally, since at least the publication of Hartmann Schedel's 'World chronicle'. A concept of German civitas was often invoked to counter charges of barbarian failings, and expressions of civic pride (Städtelob) frequently acted as the conduit for national patriotism. National patriotism was inextricably tied to regional attachments, achievements, and ambitions. ${ }^{16}$

In 1512 , Johannes Cochlaeus, inspired by Celtis's call to produce a Germania illustrata, depicted a textual vision of Germany focused on towns and cities entitled Brevis Germaniae descriptio, which patriotically attributed inventions such as the catapult and the printing press to the entire German nation. ${ }^{17}$ Eight years later in 1520 , Johannes Boemus (a monk of the Teutonic order) wrote his Omnium gentium mores. He imagined the Germans as a single people alongside other typological 'nations' dispersed across a largely pre-Columbian world. Boemus's systematic ethnography was inspired by Herodotus's understanding that all distinct peoples 'are products of common language, religion, manners, and custom - and followed the ancient author's curiosity about things like dress, diet, and dwelling'. ${ }^{18}$ Boemus's work remained a normative ethnographic authority throughout the century. Climate was causally linked to the formation of character, and the sartorial habits, funeral customs, and bridal songs of a given people revealed their underlying traits.

At the same time as this interest in human diversity was taking hold, European (and indeed, German) natural philosophers - stimulated by American and Asian discoveries - began to explore exotic and familiar plants, animals, and minerals in new ways. ${ }^{19}$ They looked inwards as well as outwards, initiating what Alix Cooper describes as 'the invention of the indigenous'. This postColumbian naturalism resulted as much in the consolidation of national and regional identities as it did a newfound scientific cosmopolitanism interested in 'wonderous particulars' from distant lands. ${ }^{20}$

For his expanded second edition of the Cosmographia $\left(155^{\circ}\right)$, Sebastian Münster tied Germany's 'magnificent cities', natural landscapes, abundant wildlife, and rich mineral deposits together, praising innate German superiority with reference to humanists and ancient authors. ${ }^{21}$ Münster called upon

16 Strauss, Sixteenth-century Germany, p. 10.

17 Johannes Cochlaeus, Brevis Germaniae descriptio... (1512).

18 Smith, Germany, p. 55; Johannes Boemus, Mores, Leges, et Ritus Omnium Gentium (Lyon, $1541)$.

19 See Christine R. Johnson, The German discovery of the world: Renaissance encounters with the strange and marvelous (Charlottesville, VA, 2008).

${ }^{20}$ This is a reduction of the argument laid out by Cooper: Alix Cooper, Inventing the indigenous: local knowledge and natural history in early modern Europe (Cambridge, 2007); for Renaissance natural philosophy, the concept of wonder, and the coming of 'New Science', see Lorraine Daston and Katherine Park, Wonders and the order of nature, II5O-I75O (New York, NY, 1998), especially pp. $215^{-303 .}$

21 Jasper van Putten, Networked nation: mapping German cities in Sebastian Münster's Cosmographia (Leiden, 2018), p. 40. 
German princes, bishops, burghers, and artists-Catholics, Lutherans, and Calvinists - to contribute images and texts to a work cataloguing the 'whole world', with over half his publication devoted to depicting an idealized German nation comprised of locally commissioned chorographical studies pars pro toto (as parts of the whole). Each German contribution competed with the others to put their city or territory at the forefront of the German nation. In this sense, the 'Cosmographia's role in the formation of German collective identity can be understood only in the context of the book's collaborative production.' ${ }^{22}$

\section{I}

Münster inherited the task of visualizing Germany (and the rest of the known world) from his humanist predecessors. However, the political and religious conditions under which he compiled the Cosmographia had changed considerably since the age of Maximilian I.

Charles V succeeded to the imperial throne in $15^{19}$, and had expanded imperial and Habsburg dynastic ambitions well beyond the German lands, central, and transalpine Europe-inheriting the crowns of Burgundy $(15 \mathrm{ob})$ and Spain $\left(15^{16}\right)$ - and looked towards colonial ventures in the Americas to vindicate further his claim to universal monarchy and fill his coffers. ${ }^{23}$ Charles's new subjects sailed the Atlantic in search of land and riches under the imperial standard, now emblazoned with the pillars of Hercules (the limits of the Old World) and the motto Plus Ultra (still further). Moreover, the Reformations had caused a substantial shift in German political order. After the defeat of the Schmalkaldic league of Protestant princes and cities at the battle of Mühlberg in 1547 , Charles had sued for concord and a religious settlement, culminating with the Peace of Augsburg in 1555. The conditions of this peace meant that conflicting views of the empire began to emerge. Many German Protestants optimistically looked towards the empire as a national confederation through which their protection and rights would be guaranteed (frequently invoking the concept of deutsche Libertät), whereas Catholics often saw it as a vehicle for Counter-Reformation universalism and the sword with which to smite Protestant heresy. ${ }^{24}$ Concurrently, anti-imperial visions of Germany also took hold among some Protestants, a response to the alarming persistence of-increasingly - 'un-German' Habsburg dynasts at the apex of imperial politics. ${ }^{25}$

${ }^{22}$ Ibid., p. 8.

${ }^{23}$ Brady, German histories, pp. 207-9.

${ }^{24}$ Ibid., pp. ${ }^{248-}{ }^{\mathrm{O}}$; Schmidt, Vaterlandsliebe, p. 212 ; for discourses of German liberty, see Hirschi, Wettkampf, pp. 389-404, 413-40; Georg Schmidt, 'Die Idee "deutsche Freiheit": Eine Leitvorstellung der politischen Kultur des Alten Reiches', in Georg Schmidt et al., eds., Kollektive Freiheitsvorstellungen im frühneuzeitlichen Europa (I40o-I850) (Frankfurt am Main, 2006), pp. 159-82; for confessional politics and nationhood, see Lau, Teutschland, pp. 24-35.

${ }^{25}$ For anti-imperial nationalism, see Hirschi, Wettkampf, pp. 464-73. 
The Austrian Catholic, Wolfgang Lazius, who was greatly informed by the geological studies of Georgius Agricola, tied the observable and unobservable features of German land and people together in his $15^{61}$ historical atlas Typi chorographici proviniciarum Austriae, a flattering panegyric to Habsburg supremacy. Lazius's claims were underpinned by the concept of a single Volk first outlined in his 1557 work De gentium aliquot migrationibus, where he examined the movements of ancient German tribes before the fall of Rome; fleshing out Beatus Rhenanus's concept of Völkerwanderung (the wandering of the peoples), and furnishing its pages with costume images depicting the wardress of ancient tribesmen. ${ }^{26}$ Influenced by earlier humanists, Lazius conjoined ancient historia, ethnography, and natural philosophy to present the German peoples as a single Volk who had conquered the whole of Europe; even claiming the land they once inhabited as belonging, inalienably, to the Volk and their natural rulers, the Austrian Habsburgs.

Nonetheless, the majority of topographical-historical works were now produced by Protestant authors; dedicated not to Habsburg rulers and their ambitions for universal monarchy, but to territorial princes; their ties to German land; and their independent claims to atavistic Germanness. Humanist discourses on German nationhood remained the central point of reference, and ancient descriptions such as Tacitus's Germania continued to provide the normative authority for most considerations of a national fatherland. ${ }^{27}$ However, the old motives for visualizing nationhood amidst a background of imperial reform and rejuvenation quickly waned. These objectives were superseded by the confessional motives of Protestants in particular. Topographical-historical works of the second half of the sixteenth century were characterized by the shifting loci of patriotic fixation: a turn from civic pride (Städtelob) to territorial pride (Territorialstaatslob). While Lazius was forming his patriotic vision of Germanness in the context of a wider Habsburg empire, numerous topographical-historical works were produced by Reformed and Lutheran Germans. Often, these extolled the irenic merits of a national fatherland (united by history, language, and culture) over confessional division. ${ }^{28}$ Inheriting the comparative framework of olim and nunc (then and now), popular works such as the Newe Chorographie, by Lutheran theologian Jakob Schopper $\left(1545^{-1616)}\right.$, and the ${ }_{1578}$ Teutscher Nation Heldenbuch, by the Swiss Heinrich Pantaleon, compared ancient Germania with their contemporary Germany and constructed a clear

${ }^{26}$ Wolfgang Lazius, Vienna Austriae. Rerum Viennesium commentarij in quator libro distincti (Basel, 1546); De gentium aliquot migrationibus, sedibus fixis, reliquijs, linguarúmq[ue] initijs $\mathcal{E}^{2}$ immutationibus ac dialectis libri XII... (Basel, 1557); Typi chorographici proviniciarum Austriae cum explicatione earundem pro commentariis rerum austraicarum concinnati... (Vienna, 1561). I am indebted to Dr William O'Reilly for information on Wolfgang Lazius. Dr O'Reilly is currently working on an upcoming article concerned with Lazius's understudied oeuvre.

${ }^{27}$ For continuity of Humanist discourses, see Hirschi, Wettkampf, pp. 441-62; Schmidt, Vaterlandsliebe, p. 128.

${ }_{28}$ Ibid., p. 133; for irenicism, see Whaley, Germany, pp. 462-76. 
continuity. Predictably, such works were highly tendentious. They emphasized the genealogies of princely houses and their connections to 'ancient' German territories and landscapes, indigenous German piety, simple morality, and concurring traditions of anti-curial sentiment. ${ }^{29}$

The Reformed Heidelberg jurist Marquard Freher dedicated his 1595 Originum Palatinarum to the Wittelsbach Count Palatine Friedrich IV (a Calvinist), describing the beginnings of the Electoral Palatinate and the Wittelsbachs from ancient times to the contemporary. Citing Bebel, Lazius, and numerous ancient and medieval authorities, he linked the Wittelsbachs' origins to the river Rhine, Heidelberg, and the 'ancient' German nation. He wrote, with an eye to flattering his prince, 'I consider it necessary to restore our nourishing and gracious German fatherland, now divided into territories (who before were unconscious of themselves) until we attempt to lawfully revive its existence.' $3^{\circ}$ A few lines later, Freher qualifies this call for German unification under the Wittelsbachs as a matter of historical and religious duty:

The Rhenish nobles are jointly in error, and on top of that they offend, in their failure to recognize the territories rightfully belonging to the count palatine of the Rhine; how swiftly they have forgotten, that along with the honour of Lord of the Rhine, come territories stretching to the alps, and furthermore, according to both antiquity and religion, the abbey which bound together the whole of Germany, most ancient and renowned: namely, the unforgettable endowment of Lorsch [to Conrad ( $1135^{-95}$ ), the first hereditary count palatine of the Rhine].31

The Germany which Freher calls to be united and 'restored' under the Calvinist Wittelsbachs was roughly coterminous with the Rhine-Danube kernel and imagined despite the empire.

The second half of the sixteenth century saw also the European (German, French, and Italian) costume book genre reach its maturity. ${ }^{2}$ In their German contexts, many of these books and alba (for they appeared in both printed and manuscript formats) expanded and assisted the scholarly and artistic programme of identifying, defining, and illustrating Germany and

29 Schmidt, Vaterlandsliebe, pp. 174-89.

$3^{\circ}$ Marquard Freher, Originum Palatinarum... (Heidelberg, 1595 ), p. 44.

$3^{1}$ Ibid., p. 44.

$3^{2}$ Christoph Weiditz's (c. 1529-32) album perhaps represents the first example of an ethnographic costume collection; see Theodor Hampe and Christoph Weiditz, Das Trachtenbuch des Christoph Weiditz von seinen Reisen nach Spanien (1529) und den Niederlanden (1531/32), nach der in der Bibliothek des Germanischen Nationalmuseums zu Nürnberg aufbewahrten Handschrift herausgegeben von Dr. Theodor Hampe (Leipzig, 1927); Elizabeth Hill Boone, 'Seeking Indianness: Christoph Weiditz, the Aztecs, and feathered Amerindians', Colonial Latin American Review, 26 (2017), pp. 39-61; Katherine Bond, 'Costume albums in Charles V's Habsburg Empire (1528-1549)' (Ph.D. diss., Cambridge, 2017), pp. 49-1 28. However, for costume books in their later sixteenth-century European and 'global' contexts, see Jones 'Habits, holdings, heterologies'; Paulicelli, 'Mapping the world'; Mariana Françozo, "Inhabitants of rustic parts of the world", John Locke's collection of drawings and the Dutch empire in ethnographic types”, History and Anthropology, 28 (2017), pp. 349-74. 
Germanness. At the same time, they could open up the world for 'armchair travellers'. Costume images focused on the outward, observable appearances of regions, aiming to present national or territorial characteristics pars pro toto, with each individual costume study usually representing a regional, social-typological whole.

Even when costume images hesitate to make the same factual claims as naturalia images 'taken from life' (what Peter Parshall calls imago contrafacta), they regularly demonstrate clear epistemic intent. 33 The oeuvres of artisan-artists such as Albrecht Dürer (1471-1528), Christoph Weiditz (1498-1559), and Abraham de Bruyn (1539-87) include both naturalia and costume images. 34 These emergent genres were produced and innovated together, at the same time and in the same workshops using cognate visual strategies.

Pamela Smith has shown that, as the consequence of an increasingly vibrant commercial culture, growing urbanization, and market expansion, fifteenthand sixteenth-century artisans and scholars found themselves in nearing proximity to one another, and their inevitable conjunctions led to a visual or 'artisanal' epistemology.35 The images contained in printed works by authors such as Leonhart Fuchs and Conrad Gessner, alongside the manuscript naturalia alba popular in Italy, Germany, and the Netherlands, led to a new authority for nature. Increasingly, the likenesses of individual (or grouped) natural specimens would be depicted in isolation of any other visual context, affording a perceived reliability which confirmed both the realness (in terms of a generalizable essence) of the specimen-at-hand, and its relatability to the viewer who went in search of it out-in-the-world. $3^{6}$ The authors of costume images employed analogous visual strategies, likewise abstracting their subjects from background visual context. Even more so, their captions categorically situate costume figures in geographical space, and their development, as Surekha Davies has shown, was entangled with representational innovations in map-making. ${ }^{37} \mathrm{Just}$ as for naturalia images, costume images gained authority and truth telling capability through the conjoined medias of manuscript and print. Particular examples were copied and referenced, often reinforcing their epistemic gravity,

33 Peter Parshall, 'Imago Contrafacta: images and facts in the northern Renaissance', Art History, 16 (1993), pp. 554-79; however, some costume images do claim to have been 'taken from life'; see, for example, Lia Markay, 'Aldrovandi's New World natives in Bologna (or how to draw the unseen al vivo)', in Elizabeth Horodowich and Lia Markay, eds., The New World in early modern Italy, I492-I $75^{\circ}$ (Cambridge, 2017), p. 226.

34 Wilson, The world in Venice, pp. 92-104.

35 Pamela Smith, The body of the artisan: art and experience in the scientific revolution (Chicago, IL, 2004), pp. 59-93; Pamela Smith, 'Commerce and the representation of nature in art and science', in Pamela Smith and Paula Findeln, eds., Merchants and marvels: commerce, science, and art in early modern Europe (London, 2002), pp. 1-28.

$3^{6}$ Florike Egmond describes the epistemology of sixteenth-century naturalia imaging: Egmond, Eye for detail, pp. 88-164.

37 Surekha Davies, Renaissance ethnography and the invention of the human: new worlds, maps and monsters (Cambridge, 2016), pp. 259-64. 
sometimes becoming normative ethnographic authorities in themselves. By the end of the century, encyclopaedic costume image collections had brought comparative dress cultures into the fold of learned enquiry. $3^{8}$

Dress was believed to reveal underlying truths about the character of a given people. Recording hierarchical, social panoramas (where costumes indicate estate, locality, and gender), the authors and compilers of costume images oversaw the development of a visual, comparative ethnography which could help delineate spectrums of national character. 39 Towards the end of the sixteenth century, costume collections were often moralistic in tone, but could equally demonstrate a sincere interest in both local and foreign customs and appearances. Whilst costume collections assisted in expanding the European 'global imaginary', unfamiliar subjects (such as Amerindians, Africans, and Tartars) were habitually exoticized and caricatured. $4^{\circ}$ Their striking ontological differences were contrasted with systematic, local panoramas of more familiar central and western European territories, whose visible - national, regional, and temporal-alterities were often more carefully graduated. $4^{1}$ Occupying a unique position in costume image collections, subjects of the Ottoman empire were often depicted as semi-exotic and semi-familiar. In the German context, they were frequently depicted as an anti-society which paralleled central European civilization. ${ }^{2}$ Panoramic costume studies of Ottoman society (including Christians, Muslims, and Jews) titillated audiences who were at once fearful of Islamic expansion and fascinated by the uncanny blend of familiarity and exoticism which artists and publishers in turn sought to convey.

However, just as important as the commonalities shared between costume image collections are 'how they differed and sought to use the visualization of clothing customs to impart political and social ideals to particular audiences'.43 For example, Christoph von Sternsee's $\left(15^{2} 5^{-55}\right)$ manuscript album reflects the cosmopolitanism of Habsburg patronage networks and the interconnectedness of a transglobal empire. 44 By contrast, Sigmundt Heldt's (1528-87) album, although 'global' in scope, establishes a more sustained focus on confessional and territorial difference in German lands through depictions of clerical dress, German regional dress, and (most disproportionately) 106 images detailing the customs and costumes of his native Nuremberg. 45

$3^{8}$ Ulrike Ilg, 'The cultural significance of costume books in sixteenth-century Europe', in C. Richardson, ed., Clothing and culture, I350-I650 (Aldershot, 2004), pp. 34-5.

39 Bronwen Wilson has demonstrated this in an Italian context, Wilson, The world in Venice, pp. 70-132; for the German context, see Rublack's 'Nationhood' chapter: Rublack, Dressing up, pp. $125^{-75}$.

$4^{\circ}$ Carina L. Johnson, Cultural hierarchy in sixteenth-century Europe: the Ottomans and Mexicans (Cambridge, 2011), pp. 10-21, 231-62.

$4^{1}$ Riello, 'The world in a book', p. 302.

$4^{2}$ Colding Smith, "Depicted with extraordinary skill”, pp. 26-8, 44.

43 Rublack, Dressing up, pp. 148-9.

44 For Sternsee, see Bond, 'Mapping culture in the Habsburg Empire'.

45 For Heldt, see Rublack, Dressing up, p. 200. 
The enduringly popular printed Trachtenbuch of Hans Weigel and Jost Amman-dedicated to the Lutheran Count Palatine Ludwig VI in 1577-was unambiguously nationalistic. ${ }^{6}$ Weigel encouraged a German readership to compare their own modes of dress with the rest of the known world's; much as Cesare Vecellio would do a decade later for Italian consumers in his 1590 De gli habiti antichi et moderni di diversi parti del mondo, and as François Desprez had formerly, in his ${ }_{1} 5^{62}$ Recueil de la diversite des habits, for a French audience. 47 As Ulinka Rublack has shown, Weigel's book had a patriotic and moralizing agenda inspired by the early German humanists. In his introduction, Weigel clarifies for the reader how the habits of 'nations' bear directly on their future successes and failures. $4^{8}$ Beginning with depictions of the emperor and German princes, Weigel leads the viewer through German territories and cities before approaching the rest of Europe, Turkey, Africa, and the Americas. Using Germanness as a moral paradigm, he demonstrates the advantages of heteronormativity (an assumed sexual difference presented through binary gender), all that was honourable and ancient in German clothing, the traditional hierarchies they demarcated, and a particular emphasis on bourgeois and patrician civility. He ensured clarity by captioning each image with pithy rhyming couplets in the German vernacular, guiding comparative assessments of German and 'non-German' dress cultures. Countries in the empire, but outside of the ancient Rhine-Danube heartland, such as Burgundy, Switzerland, Bohemia, Silesia, and the Netherlands, were still 'marked by decent respectability among the upper classes'.49 However, if we compare the image of a Nuremberg maiden with a Venetian bride (Figure 1), we see how restrained, elegantly constructed dress indicates simple German morality and industriousness contra Italian permissiveness and vanity. It was through the dress of women that Weigel could best articulate moral difference in sixteenth-century Europe. $5^{\circ}$ Moving farther out, the costumes of Turks, Africans, and Brazilians are stereotyped. Their exoticized costumes suggest societies which existed outside of European historical time, an existential gap that was understood in terms of both temporal and spatial difference. ${ }^{5}$ Weigel not only reinforces the pre-eminence of simple German values projected visibly through codes of dress compared with 'non-German' Europe, he also allows for uncomplicated stereotypes to be applied to regions across an expanding human universe, and defines, negatively, the 'whole world' in contrast with German moral supremacy.

$4^{6}$ Hans Weigel, Habitus praecipuorum populorum, tam virorum quam foeminarum singulari arte depicti... (Nuremberg, 1577).

47 Paulicelli, 'Mapping the world'; Jones, 'Habits, holdings, and heterologies'.

$4^{8}$ Rublack, Dressing up, pp. 133-4.

49 Ibid., p. 160.

$5^{\circ}$ Ibid., p. 149 .

$5^{1}$ For temporalities and exoticism, see Riello, 'The world in a book', p. 3 o6. 

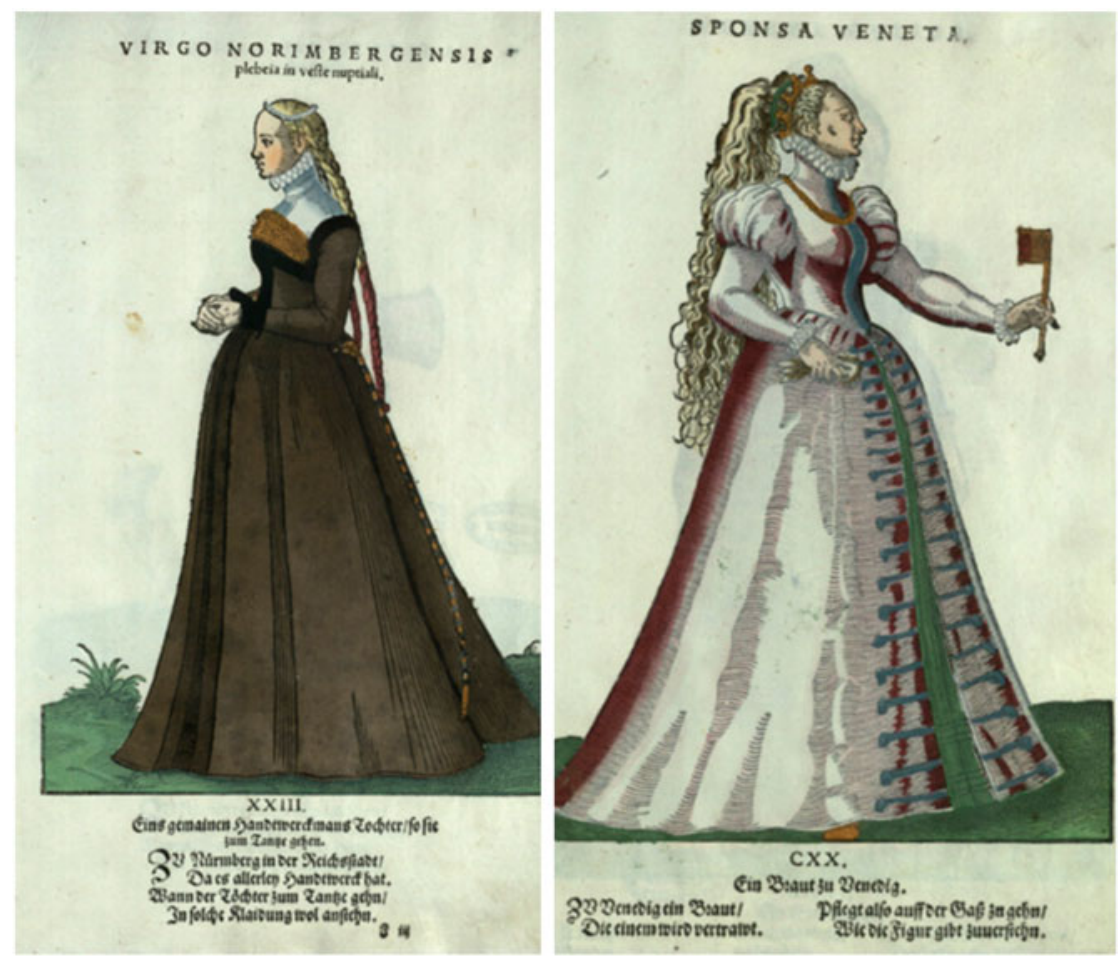

Fig. 1. A demure maiden from Nuremburg (left), and a Venetian bride holding a mirror (right), Hans Weigel and Jost Amman, Trachtenbuch... (1577), pp. 23, 122. (C) Trinity College, Cambridge

Describing costumes from across the globe, Abraham de Bruyn's $15^{81}$ printed costume book, Omnium pene Europae, Asiae, Aphricae atque Americae gentium habitus, is more ambivalent than Weigel's moral geography and somewhat broader in its scope. Nonetheless, whilst highlighting some regional difference, de Bruyn imagines cultural unity among the Germans, especially the noble and patrician classes. He provides captions for nationally stereotyped images such as 'Aulicus Germanicus' (a German courtier), and praises the 'honourable dress' of German urban elites ('In superire Germania civis honestus habitus'). $5^{2}$ Furthermore, a number of his images appear either to have been copied from Weigel's book or from the same source materials, 53 and de Bruyn's images correspond closely with Weigel's spectrum of Germanness.

$5^{2}$ Haydn Williams, 'Additional printed sources for Ligozzi's series of figures of the Ottoman empire', Master Drawings, $5^{1}$ (2013), pp. 195-220.

53 Abraham de Bruyn, Omnium pene Europae, Asiae, Aphricae atque Americae gentium habitus... (Cologne, $15^{81}$ ), p. 9 . 
Signified by the language of costume, German respectability is extended to the elites of lands outside the Rhine-Danube heartland, but inside the empire.

Printed costume books such as Weigel's and de Bruyn's - supplied to a large audience-could help better articulate the visible and invisible qualities of Germanness with reference to geographical space, history, and alterity. They could function as comparative ethnographic atlases, epistemologically and practically linked to works of cartographic, natural philosophical, cosmographic, and topographical-historical interest. They would serve to visualize and substantiate the German ethno-geographic imaginary as never before, at the same time bringing 'global' difference into the hands of 'armchair travellers'. Nevertheless, these authors constructed idealized realities for their audiences. They discerned which images to commission, to copy, and which to ignore. 54 With each iteration, particular costume images could gain, lose, or consolidate their ethnographic and ideological significations.55 Accordingly, historians must take care to consider the precise context in which individual costume image collections were compiled.

\section{I I}

The original order of Marcus zum Lamm's Thesaurus Picturarum (1 $5^{64-1606)}$ is unknown today and six volumes have been lost to us. $5^{6}$ Despite uncertainties about the original ordering, the surviving collection of costume images reveals an ethnographic, visual conception of Germany, since they have either been labelled as representing explicitly 'German' costume, or as depicting people belonging to German regions or metropolitan territories; the same can be said for those depictions of people not belonging to the German lands. The majority of zum Lamm's German images are contained in the volume known as Costumes (vol. xxIII). This volume includes visual studies of Roman military costume; medieval German kings, emperors, and nobles; fifteenthand early sixteenth-century German dress; topographical-historical entries, as well as panoramic contemporary costume studies $\left(15^{6} 4^{-1606}\right)$ representing most social stations from the following cities and regions: Regensburg, Swabia, Augsburg (Figure 2), Nuremberg (Figure 3), Basel, Strasbourg, Heidelberg, Worms, Cologne (Figure 4), Mainz, Frankfurt, Marburg (Figure 5), and Amberg (some images of Westphalians and citizens of Münster are missing). Many of the images depict occasional dress for weddings, dances, and for mourning, alongside everyday attire in both cities and the countryside. When depicting country peasants (Figure 6), zum Lamm often indicates if they are on their way to market, or if they are dressed for some occasion in the

54 Ilg, 'The cultural significance of costume books', p. 43.

55 For a discussion of early modern visual intertextualities, see Suzanna Ivanič, 'The construction of identity through visual intertextuality in a Bohemian early modern travelogue', Visual Communication, 14 (2015), pp. 49-72.

$5^{6}$ For the Thesaurus's afterlife, see Hepp, Religion und Herrschaft, pp. 19-22. 


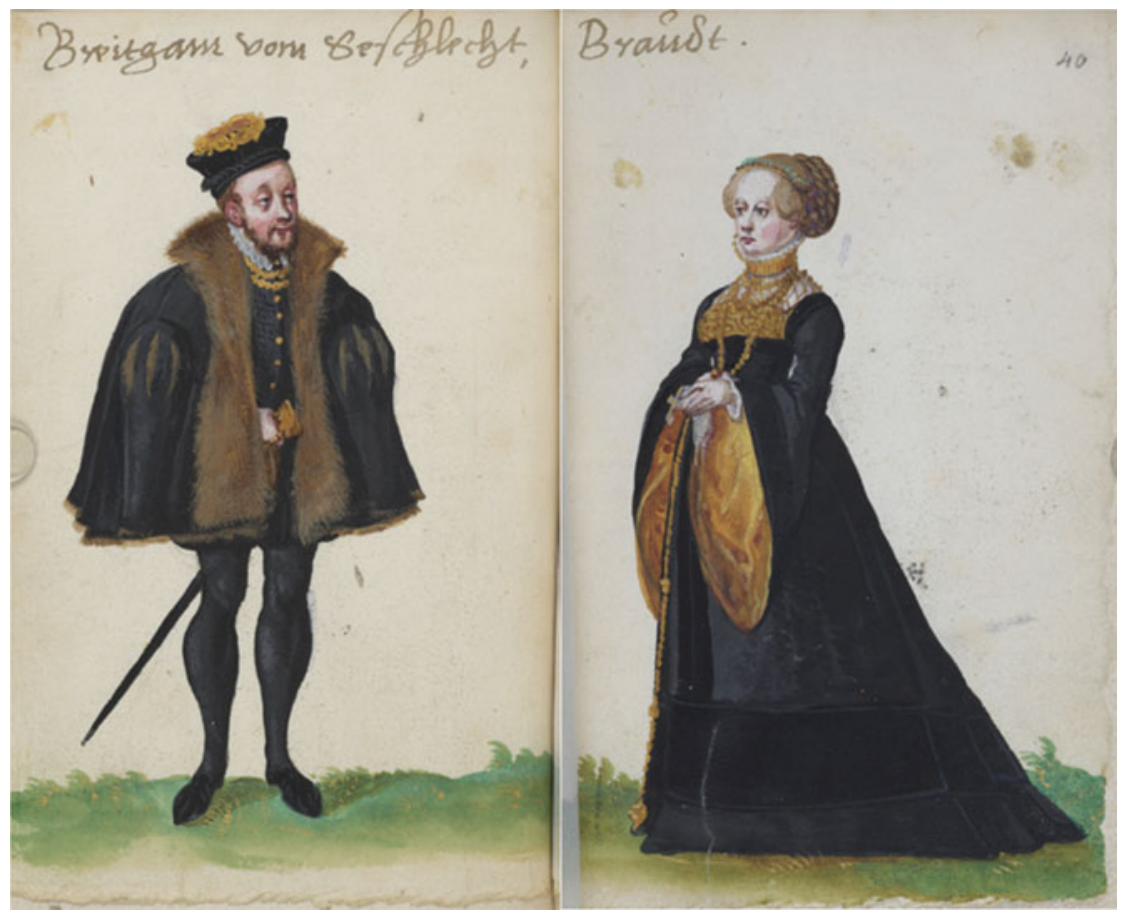

Fig. 2. Patrician groom and bride from Augsburg, Marcus zum Lamm, Thesaurus Picturarum (c. 1564-16o6), 32 vols., ULB Darmstadt, Hs. 1971, xxiII, fos. 39r, 4or. (C) ULB Darmstadt

village, for example Heimführung der Dorff Bräute im Schwaben Landt (the homecoming of village brides in Swabia). The majority of zum Lamm's German costume studies depict urban dress, as far west as Strasbourg, as far south as Basel, and as far east as Amberg and Regensburg; an area roughly delimited within the Rhine-Daube heartland. Whilst some difference in regional style is articulated, more emphatic are the trans-territorial similarities between urban - patrician and bourgeois - German dress cultures.

Confession would have been a factor which influenced the extents of zum Lamm's chorographic collection of German costume studies, since most of the cities he included had largely Protestant civic majorities, and he notably excluded Habsburg territories. 57 Yet we may still be missing images. Whilst his Nuremberg contemporary Sigmund Heldt attempted to represent confession visually through a sizeable record of clerical dress from all confessions (and most holy orders), zum Lamm refrains from such detail. Nonetheless, his 'Heidelberg chronicle' (vols. IV-V) begins with a coloured cityscape of Heidelberg (Figure 7) accompanied by a Laudatio praising the reign of

57 Whaley, Germany, pp. 462-74; Lau, Teutschland, pp. 106-9. 


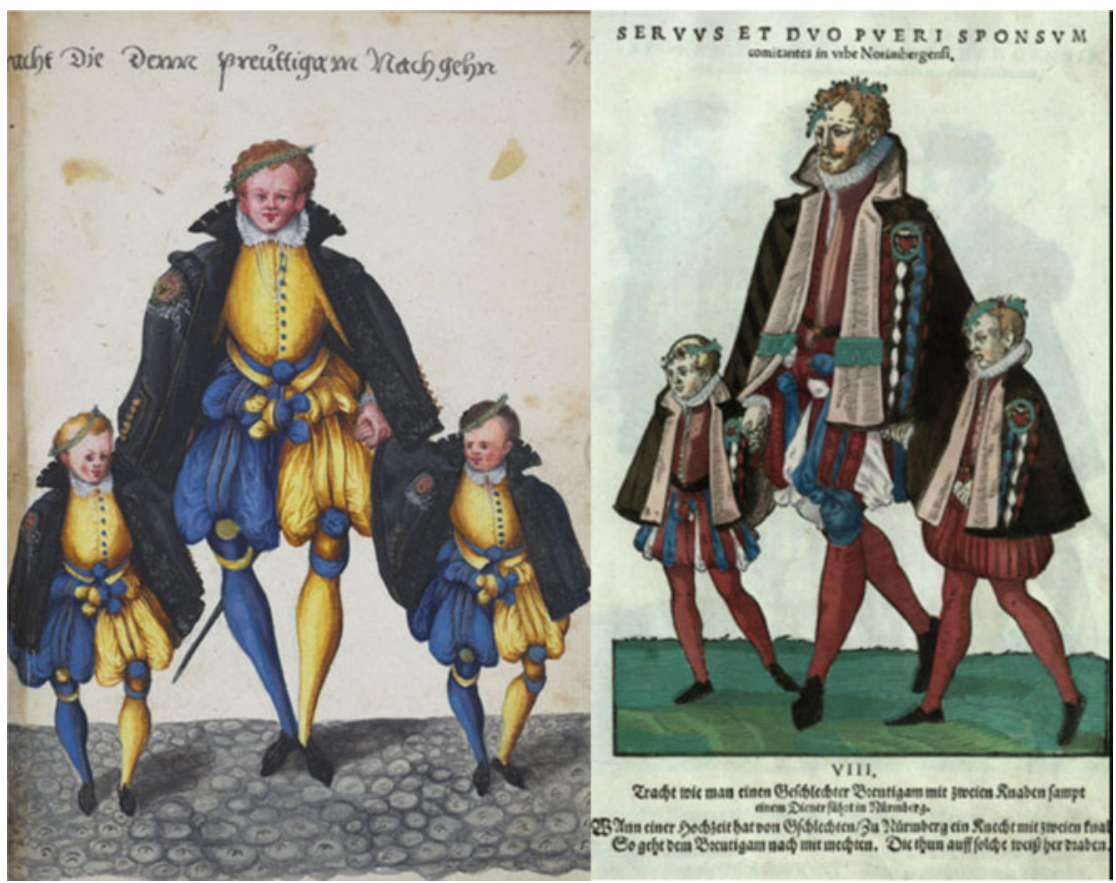

Fig. 3. Patrician groom and pages from Nuremburg (left), zum Lamm, Thesaurus Picturarum, xxxiII, fo. 76r. (C) ULB Darmstadt; copied after Jost Amman's image (right), Weigel and Amman, Trachtenbuch, p. 8 (c) Trinity College, Cambridge

Count Palatine Friedrich IV and the 'peaceful' spread of the 'New [Reformed] Religion' amongst the 'Teutons' and 'Franconians'-i.e. within the RhineDanube kernel. Furthermore, in his Prodigia et monstra volume (vol. XXVII), zum Lamm includes his own local weather observations, recorded between 1598 and 1605 in Heidelberg, alongside sixteen vernacular meteorological pamphlets detailing wondersigns, astrology, monstrous births, and prodigious weather. These were sourced from across the German lands and often prognosticate consequences for the entire 'German nation', the Habsburgs, and other German princely houses; whilst his personal observations are connected to the fortunes of the Palatine Wittelsbachs. $5^{8}$ These pamphlets expand zum Lamm's geopolitical understanding to include comparative 'greater' and 'lesser' Germanies. The former is implicitly Habsburg and imperial; its extents (so we might surmise from reading vol. XXVII) stretching eastwards from Alsace to include Innsbruck, Danzig, and Rosenberg (Hungary). The latter (suggested by zum Lamm's German costume images and topographical-historical

$5^{8}$ L. Spilger, 'Markus zum Lamm als Meteorologe I \& II', Zeitschrift für angewante Meteorologie das Wetter, $5^{6}$ (1939), pp. 368-402; zum Lamm, Thesaurus Picturarum, xxvII. 


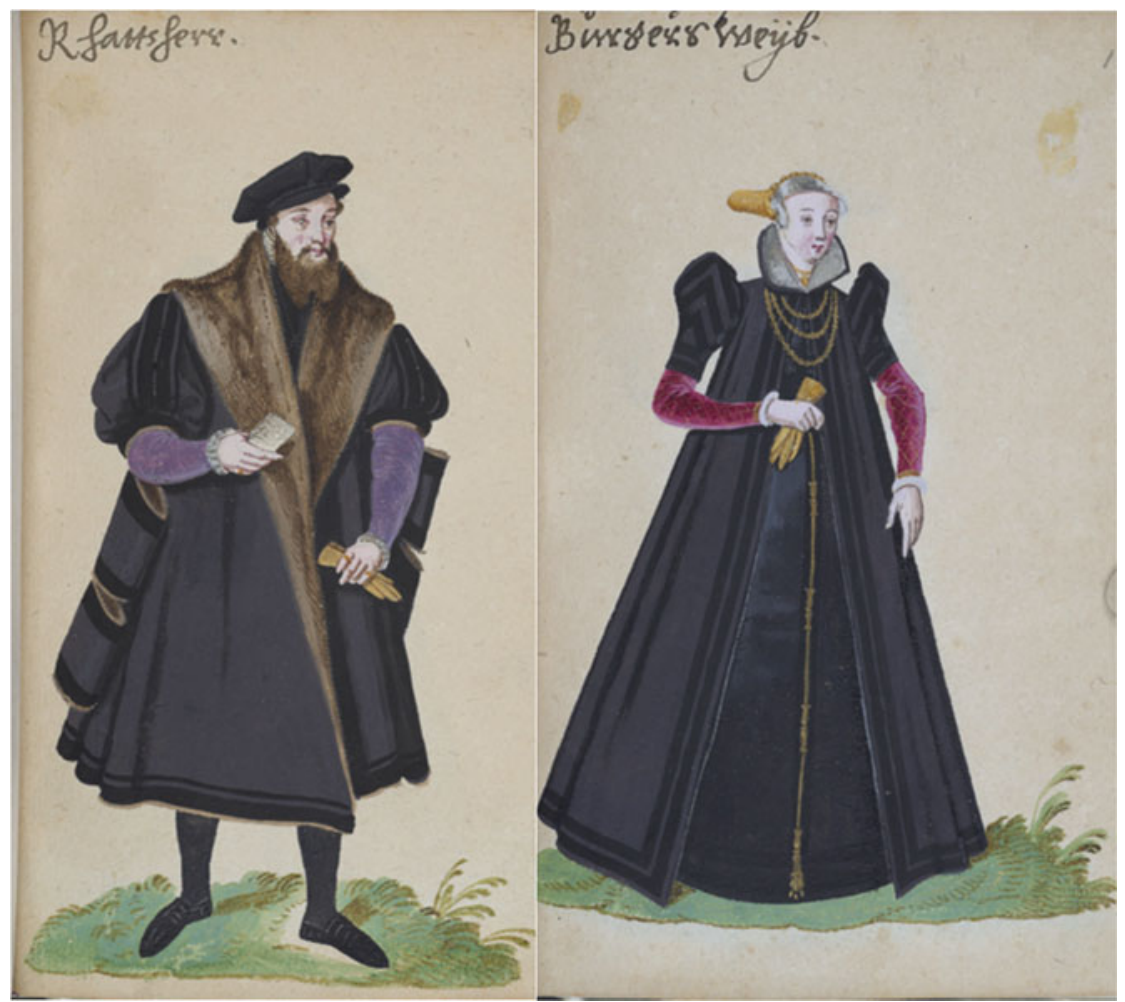

Fig. 4. Member of the city council and a 'citizen's wife' from Cologne, zum Lamm, Thesaurus Picturarum, xxxIII, fos. 131r, 132r. (C) ULB Darmstadt

entries) correlates with the German theatre of Palatine dynastic and confessional ambitions - at this moment orientated territorially towards the 'ancient' Rhine-Danube heartland and diplomatically towards France and the Netherlands. 59

The Additions volume (vol. xxxIII), whose contents are rather miscellaneous (and likely plundered from the original collection), contains more of zum Lamm's German images. These include depictions of contemporary dress in Heidelberg and Nördlingen, 'the dress of modern German courtiers', and an image of 'German military attire' (Habitus modernorum Germaniae Militum); alongside full body portraits of princes, German peasants, two figures from Flanders, Polish noblemen, a Tartar horseman, two 'Moors' riding a camel, an example of 'Saracen dress', 'Wild Laps', and a 'Gypsy'. The Turcica

59 Cornel A. Zwierlein, 'Heidelberg und "der Westen"”, in Christoph Strohm et al., eds., Späthumanismus und reformierte Konfession. Theologie. Jurisprudence und Philosophie in Heidelberg an der Wende zum I 7 Jahrhundert (Tübingen, 2006), pp. 27-92. 


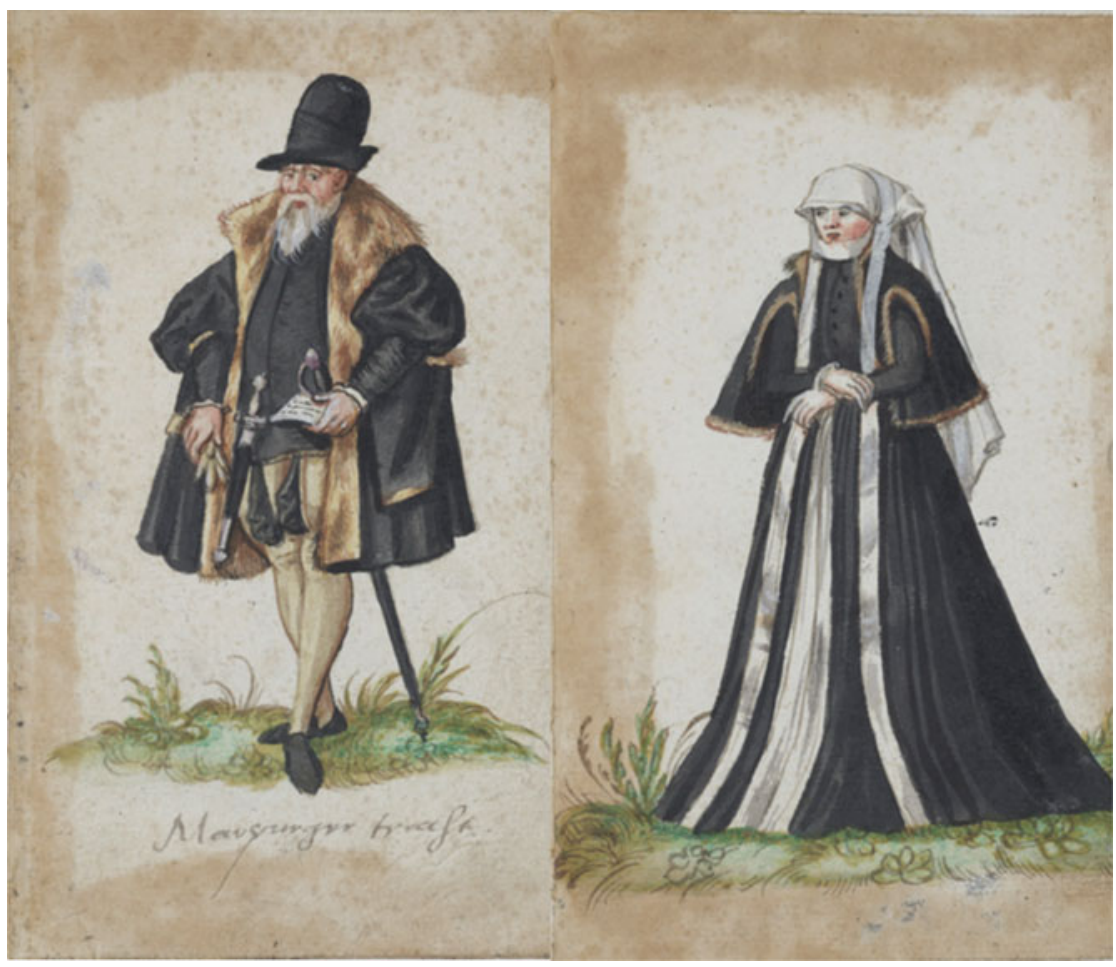

Fig. 5. Man and young woman in 'Marburger dress', zum Lamm, Thesaurus Picturarum, xxxIII, fos. 16or, 162r. (C) ULB Darmstadt

volume (vol. xv) contains only images of a more exotic variety, featuring inhabitants of the Ottoman dominions (Figure 8) and parts of Africa: sultans, viziers, muftis, and more panoramic collections of costume and social vignettes (such as picking dates in Egypt) showing daily life and dress amongst Eastern and African peoples (Figure 9).

A significant number of the costume images can be attributed to three artists: Barthel Bruyn; Friedrich von Hammel; and Wilhelm Pesser (most famous for his cartographic studies and as son of the court painter Johann Pesser) whose IW monogram is found on a number of drawings in the Thesaurus. ${ }^{60}$ The German images were produced by a number of different hands, indicating that zum Lamm's project was facilitated by a 'nationwide' network of local illuminators, artists, and patrons. Aside from Pesser (Heidelberg) and Bruyn (Cologne), these artists include M. N. Umbach (Augsburg), Herbert Luyers (Münster), Friedrich Gefrid (Nördlingen), and Heinrich Lautensack

6o Walther, 'Die Trachtenbilder im Thesaurus Picturarum', pp. 79-8o. 


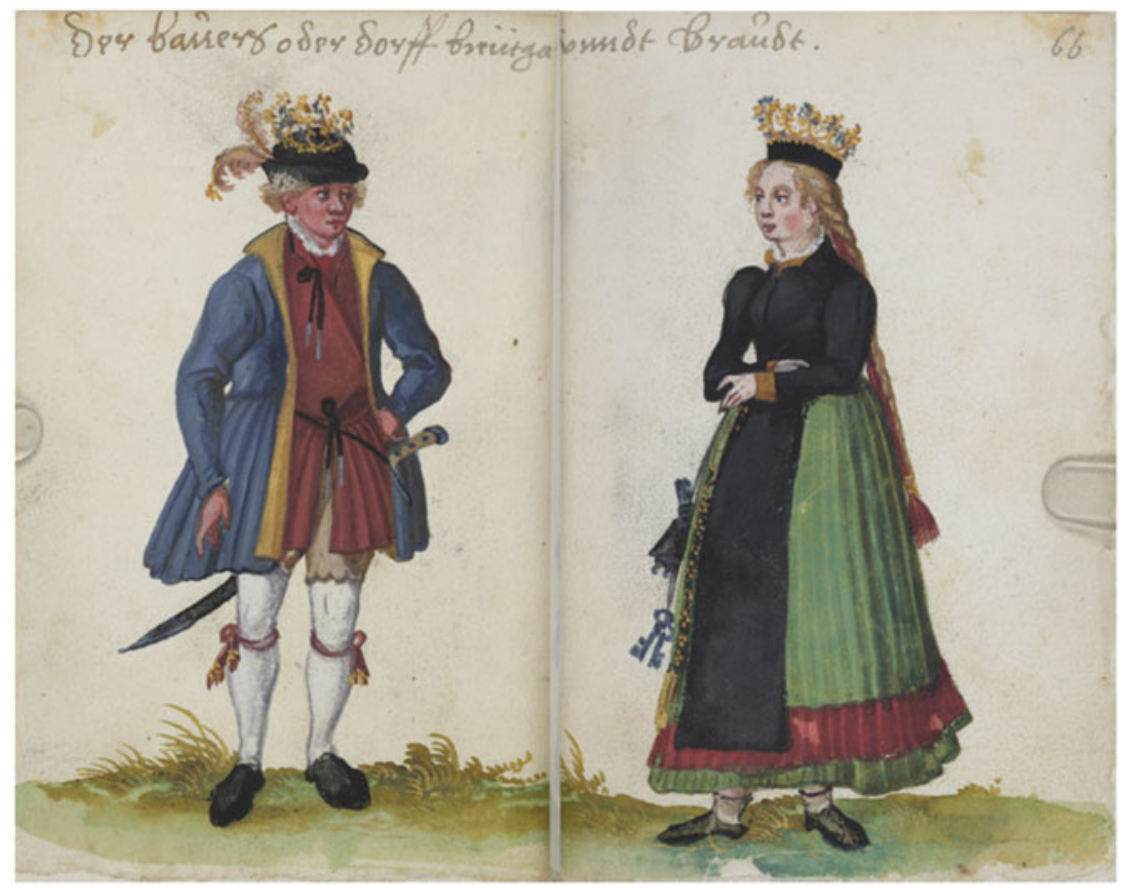

Fig. 6. Peasant groom and bride in Swabia, zum Lamm, Thesaurus Picturarum, xxxIII, fos. 65 v, 66r. (C) ULB Darmstadt

(Frankfurt). ${ }^{61}$ Zum Lamm paid no mean price for these images, 5 florins (or Reichsgulder) and 12 Kreuzer for his commission of Augsburg costumes, and $4 \frac{1}{2}$ florins for his panorama of Heidelberg costumes.

We cannot be sure of what exactly first possessed zum Lamm to begin collecting costume images. In France, he may well have come across printed costume images in Desprez's ${ }_{1562}$ Recueil de la diversite des habits, and he knew Nicolas de Nicolay's 1567 account of adventures in Ottoman Turkey, Les Quatres premieres livres des navigations et peregrinations orientales, either through French contacts or through networks in Calvinist Heidelberg, where there was also a large contingent of Huguenot scholars and refugees. In Heidelberg, he was made aware of the East Frisian costume images from Unico Manninga's Hausbuch, and here too would he have come across the printed 1577 Trachtenbuch of Hans Weigel and Jost Amman, an edition of Cesare Vecellio's 1590 costume book, and

61 Hartmut Bock, Die Chronik Eisenberger: Edition und Kommentar: bebilderte Geschichte einer Beamtenfamilie der deutschen Renaissance, Aufstieg in den Wetterauer Niederadler und das Frankfurter Patriziat (Frankfurt, 2001), pp. 306, 380, 411-13; some of the German historical costumes included by zum Lamm were likely inspired by such genealogy books. 


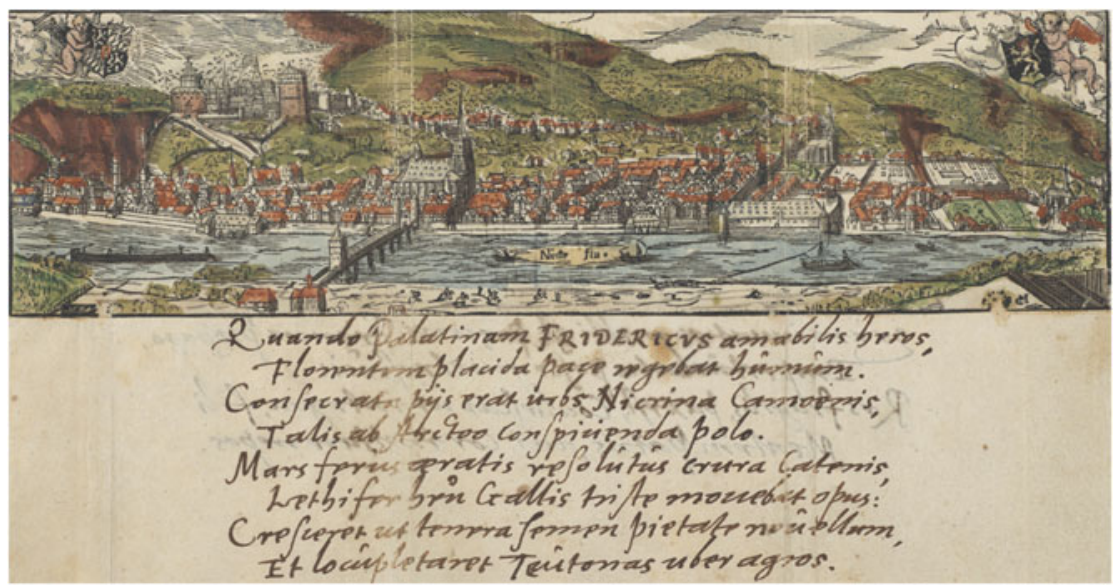

Fig. 7. Cityscape of Heidelberg accompained by an ode in praise of Elector Palatine Friedrich IV, zum Lamm, Thesaurus Picturarum, IV, fo. 8r. ㄷ ULB Darmstadt

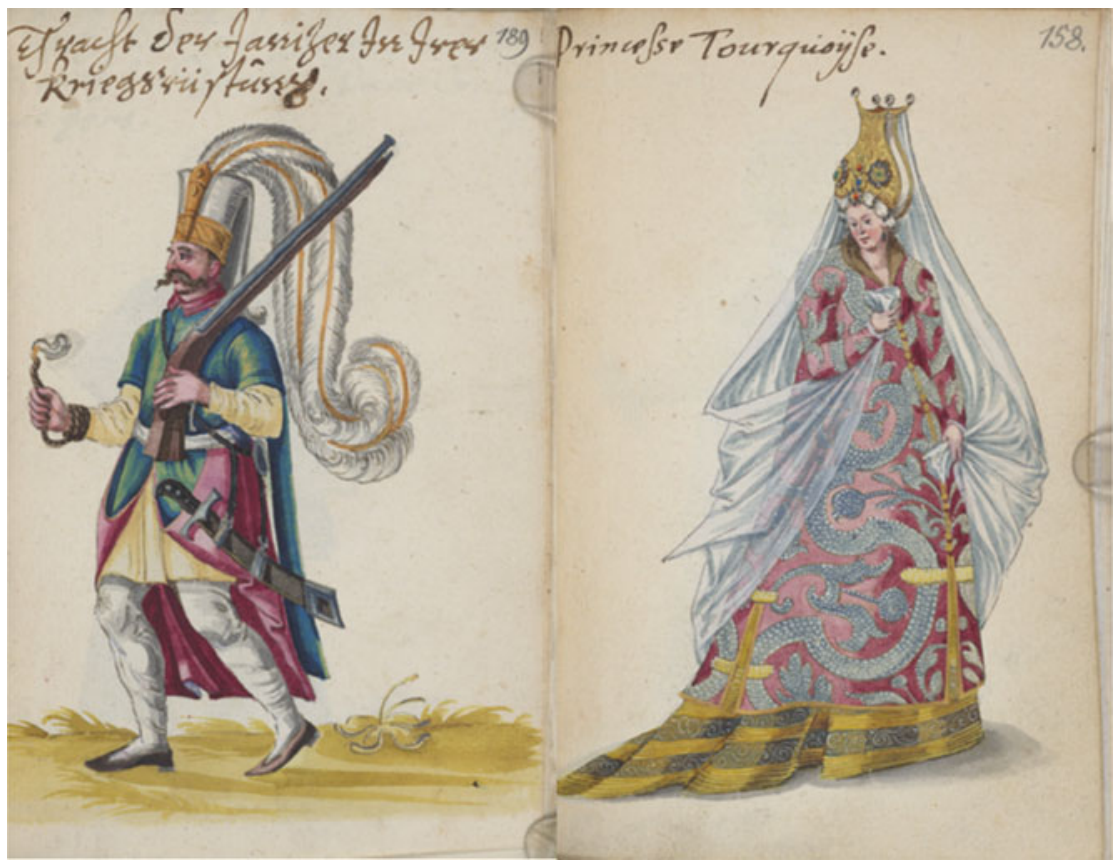

Fig. 8. Ottoman janissary after Abraham de Bruyn (left) and Turkish princess copied from Vecellio's, De gli habiti... (right), zum Lamm, Thesaurus Picturarum, xv, fos. 189 r, 158 r. (C) ULB Darmstadt 


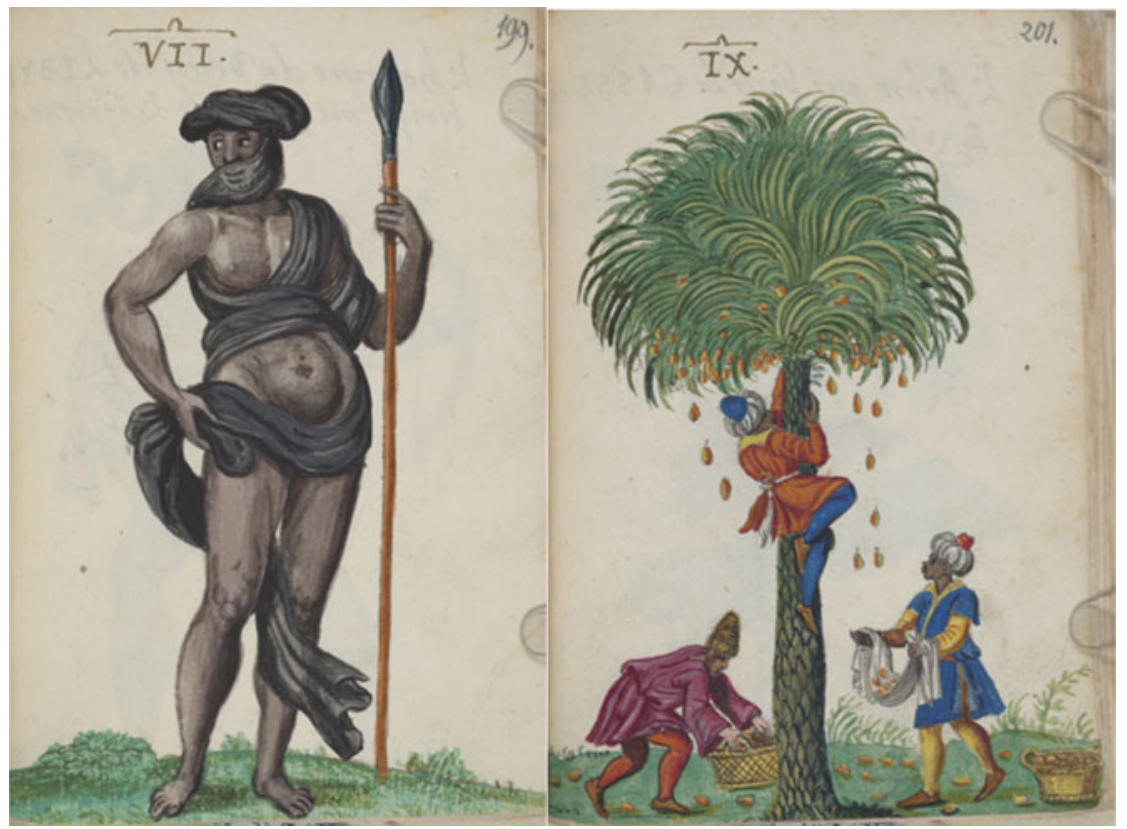

Fig. 9. 'A Gentleman of Tesset, the principle city in Numidia' (left) and date picking in Egypt (right), zum Lamm, Thesaurus Picturarum, xv, fos. 199r, 201r. (C) ULB Darmstadt

Abraham de Bruyn's $15^{81}$ publication. ${ }^{62}$ The court at Heidelberg was of central interest to zum Lamm's costume collection and his work more generallyincluding in his Thesaurus the vibrantly illustrated 'Heidelberg chronicle', mentioned above, which also contains watercolour studies of Heidelberg courtiers, visiting dignitaries, their entourages, and court festivities. Heidelberg was the locus of zum Lamm's knowledge and procurement network, and, as a hotspot of political and religious argument in sixteenth-century Europe, the Palatine capital's combined court and university cultures represented the cosmopolitan epicentre of European Calvinism. ${ }^{63}$

Alongside overlaps with the visual interests of natural philosophers, cartographers, topographers, and the cutting edge of ethnographic imagery, zum Lamm would have sourced some of his inspiration to collect German costume images from Geschlechter- and Stammbücher, which often included illustrations

${ }^{62}$ Johannes Stracke, Tracht und Schmuck Altfrieslands: Nach den Darstellungen im Hausbuch des Häuptlings Unico Manninga (Kollmar, 1967), pp. 68-76.

63 Andrew Thomas, A house divided: Wittelsbach confessional court cultures in the Holy Roman Empire, c. I550-I650 (Leiden, 2010), p. 73; Claus-Peter Clasen, The Palatinate in European history (I555-I6I8) (Oxford, 1966), pp. 36-9; Zwierlein, 'Heidelberg und "der Westen", pp. $3^{6-} 55$. 
resembling early costume studies. ${ }^{6} 4$ Since the beginning of the century, especially in Nuremberg and Augsburg, Geschlechterbücher were created with costume figures representing the different estates, and at the court in Heidelberg, Elector Ottoheinrich commissioned a genealogical tapestry (c. 1540) which similarly incorporated chorographic figures dressed in local costume. ${ }^{6}$ Zum Lamm would have seen this tapestry hanging at the electoral palace, where he may also have read Ottoheinrich's album of traditional costumes that 'strongly recall the work of Christoph Weiditz'. ${ }^{66}$ Ottoheinrich had commissioned an elaborate section on Heidelberg for Münster's Cosmographia which 'placed the ancestral lineage of the Wittelsbach line...at the core of the German nation as future elector palatine'. ${ }^{67}$ As we have seen, zum Lamm's contemporary Marquard Freher did the same for Elector Friedrich IV in his 1595 Originum Palatinarum, and zum Lamm dedicates much of his collection to praising the Wittelsbach Counts Palatine. Zum Lamm would have been aware of the work of Conrad Celtis, Heinrich Bebel, Ulrich von Hutten, Beatus Rhenanus, Sebastian Münster, and Wolfgang Lazius, as well as Freher, whose patriotic, German topographical-historical works were all available to him at the court library, the Bibliotheca Palatina, alongside numerous other apposite works of cartography, travel literature, chronicle writings, and festival books. These would have inspired the topographical-historical descriptions which prelude many of his chorographic German costume panoramas. These short entries link the history and geography of individual regions and cities to metonymic praise of the national fatherland. For example, 'Strasbourg, the primary city in Alsace, sits on a tributary which flows into the Rhine...the fertile farmland produces wine and grain of the best quality in all of Germany'; 'Cologne was first settled by the Ubii on the other side of the Rhine, until Augustus Tiberius camped his army there during his campaign against the Suebians... [and] today flourish[es] beyond all other cities of the German nation'; and, 'in Westphalia, the clothing is simple and full of ancient virtue'.

His interest in more exotic costume may not only have been inspired by reading de Nicolay, Weigel, de Bruyn, and Vecellio, but also from contact with Michael Heberer in Heidelberg, who had served time as a galley slave (his travels published under the title Aegiptica servitus in 1610), and some of zum Lamm's Ottoman pictures may have been prototype illustrations for Heberer's book. ${ }^{68}$ Zum Lamm also acquired at least two studies of Ottoman emperors from his father, copied from originals - purportedly 'taken from

\footnotetext{
64 For more on Geschlechterbücher, see Gregor Rohmann, Das Ehrenbuch der Fugger (Augsburg, $2004)$.

${ }_{5}$ Walther, 'Die Trachtenbilder im Thesaurus Picturarum', p. 78.

${ }^{66}$ H. Rott, 'Ottheinrich und die Kunst', Mitteilungen zur Geschichte des Heidelberger Schloss, 5 (1905), p. 113 .

${ }_{6}$ Van Putten, Networked nation, pp. 154-5.

68 Walther, 'Die Trachtenbilder im Thesaurus Picturarum', p. 87.
} 
life' in Constantinople-owned by a visiting imperial captain named Hans Geraltvitsky, who was hosted by the zum Lamms in Speyer for the imperial diet of $1540 .{ }^{69}$ His ancient Roman costume images were informed by Guillame de Choul's Discours de la religion des anciens romans, de la castramentation et discipline militaire d'iceux; and his African scenes are associated with the descriptions of Leo Africanus. ${ }^{\circ}$

His particular interest in the costumes, customs, and history of Ottoman Turkey and the Islamic world stemmed also from military and eschatological concerns. Several times he associates the 'Türkengefahr' (Turkish threat) with the biblical 'nations' Gog and Magog (who would bring forth Apocalypse when summoned by Satan to do battle with Christ, according to the Book of Revelations). The apocalyptic Turkish threat alarmed Reformed, Lutheran, and Catholic Germans in equal measure and on quite pragmatic grounds. Alexander Schmidt has shown that from the middle of the sixteenth century until the Thirty Years War the Turkish threat served to consolidate transconfessional visions of a cohesive Germany, in opposition to the 'Ottoman antichrist', whose armies posed a very real danger. ${ }^{71}$ Threatening both Reich and nation, the Turkish threat encouraged patriots, across confessional and territorial divisions, to galvanize the idea-image of Germany against that of an undisputed enemy. Schmidt describes how fear "served as a "communicative context", creating an enormously broad spectrum of diverse textual [and visual] genres'. $7^{2}$ Much of the material collected in zum Lamm's Turcica volume corresponds with the 'communicative context' outlined by Schmidt, only complicated by the inclusion of more ambivalent ethnographic descriptions and costume imagery, aligning the collection also with contemporary interests in wonder and the exotic. 73 Nevertheless, comparing a relatively homogeneous collection of German costumes with a heterogeneous and often exoticized assemblage of Eastern and African peoples, zum Lamm consolidates the appearance of Germanness in contrast with a dangerous, yet captivating image of alterity. 74

Zum Lamm's most salient, visual interests were birds and costumes. No other extant collection devotes such attention to collecting on both topics at once. In so doing, zum Lamm brings together the natural and human worlds in relation to one another, making less ambiguous a connection that can otherwise be surmised across the whole record of long sixteenth-century image alba, encyclopaedias, thesauri, Kunst- and Wunderkammern. For zum Lamm, nature holds up a

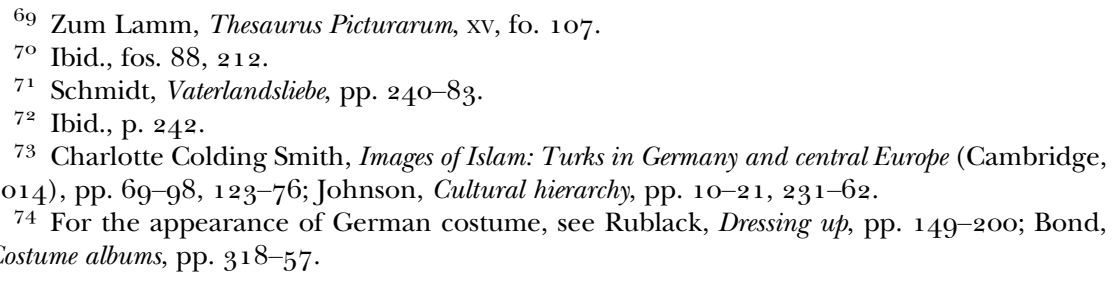


mirror (albeit a murky one) to the human world. The order of nature could be symbolically reproduced in the world of man, and vice versa. The grammars of their visual languages overlapped and could be read in analogous ways.

At the centre of zum Lamm's vision of an ornithological universe are the familiar central European bird studies of Conrad Gessner, supplemented by exotic specimens from Africa, India, and the Americas. Similarly, at the centre of his human universe, are images of past and present German costume, contrasted by images depicting the exotic costumes of Ottomans, Persians, Africans, Bulgars, Tartars, Muscovites, 'Wild Laps', and 'Gypsies'. So too are the modes of visual formatting comparable. Each costume study and ornithological specimen represents a typological whole; each figure drawn alone in space and isolated from any other visual context. Seen together, zum Lamm's images, on both topics, reveal a transcendent visual epistemology. In the same manner for costumes as for birds, the viewer is encouraged to search each image for what makes the subject-at-hand absolutely itself (although many of his costume images are more generalized), attracting the gaze towards peculiar and interesting features which make the specimen or costume study, as a pars pro toto representative, visually identifiable. 75 This allowed the viewer to discern similitudes, similarities, and divergences, symbolically and phenomenally, comparing a range of visual essences from which the world was composed.

Furthermore, particularly in zum Lamm's German costume images, there is often a clearly defined gender binary, with male examples facing a female counterpart on the opposite page; a typical feature in many costume books and alba. Although zum Lamm only identifies the sex of birds on occasion, he demonstrates a symbolically gendered dimension in his ornithology, tying the natural to the human world by making invisible human qualities visible through certain depictions of nature. This is most obvious in his depictions of Elector Friedrich IV's birds of prey, and his wife Louise Juliana of Nassau's collection of doves. The birds of prey represent the aristocratic virtues expected of a prince: intuition, vigilance, nobility, grace, and - of course - terrible power over life and death. $7^{6}$ On the obverse, the doves of Louise Juliana's collection, aside from the birds' potent association with the Holy Spirit, symbolize her demure and feminine virtues: meek, mild, pious, and dependable; the gentle bridle of her husband's powers. For zum Lamm, gendered qualities could be seen in both the human and natural worlds. In a distinctly localized sense, natural possessions could symbolize a moral order, and a hierarchy that could be reflected onto humanity. In dialogue, zum Lamm's costume and bird images articulate a moral order of things, and for both the costume and bird images, the part stood in for the whole. Whilst these two collections had as many separate functions as they did similar, the overlap illustrates zum

75 Egmond, Eye for detail, pp. 88-164.

${ }^{76}$ Ulisse Aldrovandi, Ormithologiae hoc est De auibus historiae libri XII. (Frankfurt, 1610), pp. 61-122, 221-38, 238-55; van Putten, Networked nation, pp. 166-7. 
Lamm's personal, interpretative appropriation of a 'visual epistemology' in the novel genre of a thesaurus of images. For the Calvinist zum Lamm, these images, and the world itself, had plural phenomenal and symbolic aspects which could be read dialogically to reveal hidden truths. 77

\section{IV}

Zum Lamm's ethnographic picture of Germany, then, produced in an epistemic context also very concerned with natural philosophy, topographicalhistory, and cartography, the phenomenal and the symbolic, examined a vision of Germanness through time and space. For the viewer familiar with works such as Hans Weigel's Trachtenbuch, he offers a detailed description of German costume (suggesting the familiar themes of ancient moral superiority, industriousness, and a strict gender binary) and, at the same time, depicted what was visibly exotic, heterogeneous, and ontologically un-German. The central studies of German costume represent many predictable characters; patricians, artisans, nobles, and peasants; virgins, brides, and demure wives, all of whom would have been considered straightforwardly German. However, of particular interest are the images which zum Lamm includes defining the imaginary borders of German identity.

A remarkable inclusion amongst the German costumes is a pair of images depicting a male and female Jew from Worms (Figure 10). The fact of their inclusion admits to the significant participation of Jews in German civic and commercial life (at least in the Rhineland cities). But the iconographies of these images, in particular the distinct symbols associated with this pair, reveal deeper meanings and the sophistication of zum Lamm's visual epistemology.

As Nils Römer observes, whilst emblems such as a cross or crown held in the hand might suggest the power and status of a Christian figure, the male Jew, dressed in a cloak pinned with the mandatory yellow badge and clasping a coin purse in his left hand, holds a large head of garlic in his right. Although the association with Jews and garlic was an established fixture of the period's anti-Semitic iconography, Römer asserts that in truth it represents the Jew's membership of the wider Rhineland Jewish community; particularly prominent in the cities of Speyer, Worms, and Mainz. These cities were collectively abbreviated as Shum, a homonym of the Hebrew word for garlic, this verbal-pictorial pun acting to affirm the figure's ancestral and local identities. Opposite him, a Jewish woman, wearing a black dress and a starched wimple, holds a goose interpreted by Römer to reference the House of the Goose on Worms's Judengasse. $7^{8}$

77 Anne-Charlott Trepp, 'Im "Buch der Natur" lesen: Natur und Religion im Zeitalter der Konfessionalisierung und des Dreißigjährigen Krieges', in Anne-Charlott Trepp and Hartmut Lehmann, eds., Antike Weisheit und kulturelle Praxis: Hermetismus in der Frühen Neuzeit (Göttingen, 2001), pp. 103-43.

$7^{8}$ Nils Römer, German city, Jewish memory: the story of Worms (Hanover, 2010), p. 34 . 


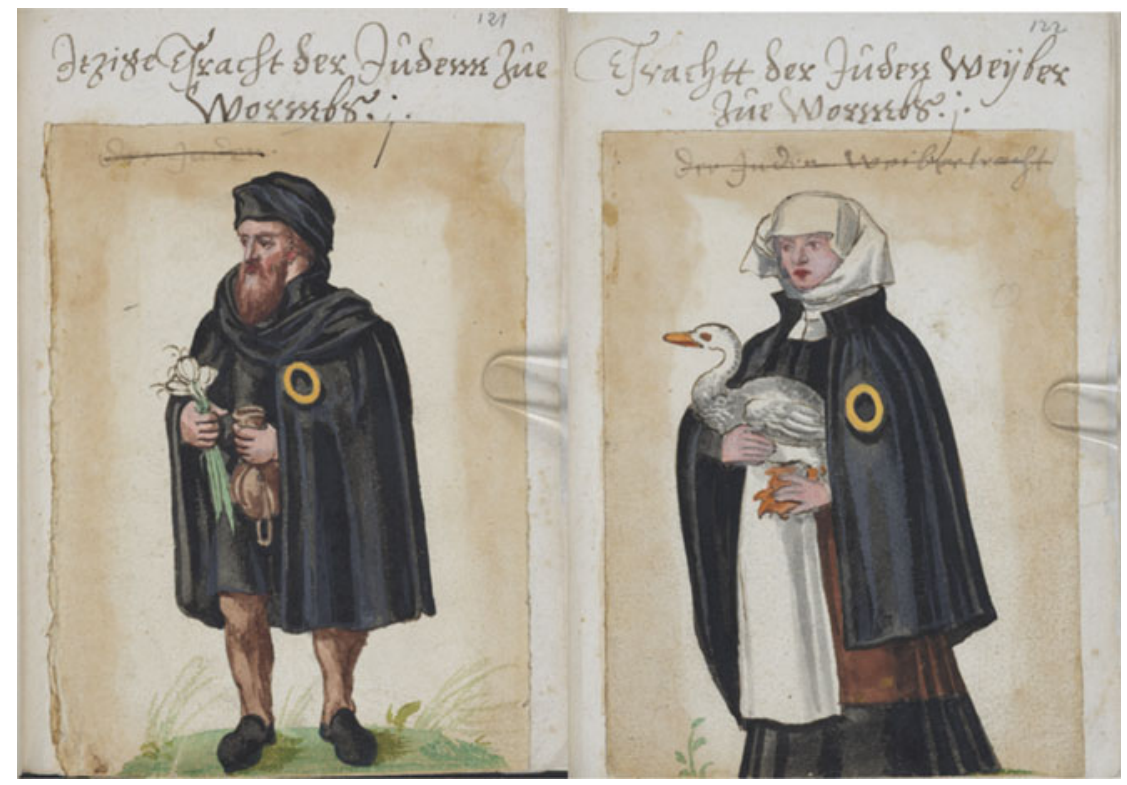

Fig. 10. The dress of a Jewish man and woman from Worms, zum Lamm, Thesaurus Picturarum, XXXIII, fos. $121 \mathrm{r}, 122 \mathrm{r}$. (C) ULB Darmstadt

In fact, the goose discloses a deeper symbolism. It is an allusion to the massacre of the Rhineland Jews (including 8 oo Jews in Worms) by the 'People's Crusade' under the leadership of Count Emicho in 1096. Indeed, what particularly distinguished Emicho's crusader army-more a rabble of French and German peasants - from other fanatics intent on Jerusalem, was that they followed a goose believed to contain the Holy Spirit who would guide them towards the Holy Land. On reaching the Rhineland, Emicho's men, whipped into a frenzy by rumours of Jewish crimes against Christians, seized their imagined blood-debt without mercy. 79

Following this interpretation, we can approach this pair of images in either of two directions. First, that they may be read as part of the era's arsenal of antiSemitic iconography, violently mocking the Rhineland Jews' localized 'Jewishness', and the memory of their precarious position in German society. On the other hand, they may deploy a sincere, compassionate evocation of Jewish memory; evoking appalling atrocity, association, and identity; encouraging sympathy from the viewer and affirming the humanity of these figures. By consciously including pictures of Jews as part of his precise vision of Germany, zum Lamm suggests a tolerant, if not inclusive, image of

79 August Krey, The first crusade: the accounts of eyewitnesses and participants (Princeton, NJ, 1921 ), pp. 52-3; Steven Runciman, A history of the crusades: the first crusade and the foundation of the kingdom of Jerusalem (Cambridge, 1951), p. 64 . 
Germanness. They are situated distinctly as 'Jews from Worms' - where Jews were even afforded citizenship-opposed to the 'wandering Jew' of antiSemitic myth. They are tied to a regional economy, topography, and specific memories of atrocity. Although still compromised and distinguished by their 'Jewishness', when compared with the image of an Ottoman Jewish merchant copied from Abraham de Bruyn (Turcica, vol. Xv) (Figure 11), we see that, for zum Lamm, regional Jewish identities could be perceived visually, both by the appearance of 'Jewishness' and by locally specific signifiers which could ensure 'Germanness' or 'Easternness'.

In zum Lamm's Turcica volume (vol. xv) we find a series of eight costume images which claim to represent the people of Phrygia, introduced under the title Phrygia Orientalis Habitus Praecipuss et singularis. In zum Lamm's own words, the Phrygians inhabit

a part of Asia, Carthea, opposite where Ilium, now called Troy, is located. Today they are subjects of the Turkish empire. The landscape is famous for, and distinguished by, its deposits of gold and silver. But the people there have a wild constitution and a servant-like folly. Therefore, Terence says that the Phrygians only become wise by misfortune. Their Gods are the stars they worship. As such, they decorate their clothes with the figures of heavenly signs that they have artfully engraved in gold. ${ }^{80}$

The images included by zum Lamm match this description (Figure 12). But these are not pictures of Phrygians. They are of East Frisians, a people inhabiting the north-western margins of Germany. Ulinka Rublack, Johannes Stracke, and Friedrich Ritter have all highlighted this misnomer, but none have attempted a detailed explanation for this intriguing transposition of Phrygians (Phrygii) over Frisians (Frisii or Phrysii). ${ }^{81}$

The images of East Frisians, labelled as Phrygians, are taken from the Hausbuch (c. $15^{61-88}$ ) of Reformed East Frisian chieftain (Häuptling) Unico Manninga, whose images came to the attention of zum Lamm through the chieftain's connections in Heidelberg; where there had been a significant contingent of East Frisian students since the late middle ages. ${ }^{82}$ We do not know whether zum Lamm would have seen Manniga's images in their original manuscript form, or through copies circulating in print. Nevertheless, zum Lamm would certainly have been aware that these were Frisians and not Phrygians, because the model images - in either format-are clearly labelled as so, and zum Lamm undoubtedly had some contact with East Frisians in Heidelberg.

Earlier, in the mid-fifteenth century, one Italian student, surprised by the eloquence of a speech delivered by the Frisian scholar Rudolphus Agricola Phrysius at the university of Padua, asked another if they knew the identity of

\footnotetext{
80 Zum Lamm, Thesaurus Picturarum, xiII, fo. $176 \mathrm{r}-\mathrm{v}$.

81 Rublack, Dressing up, 162; Stracke, Tracht und Schmuck Altfrieslands, pp. 68-76; Friedrich Ritter, 'Manninga-Bilder in der Hofbibliothek zu Darmstadt', Jahrbuch der Gesellschaft für bildende Kunst und vaterländische Altertümer zu Emden, 14 (1902), pp. 466-8.

82 Rublack, Dressing up, p. 162; Stracke, Tracht and Schmuck Altfrieslands, p. 69.
} 


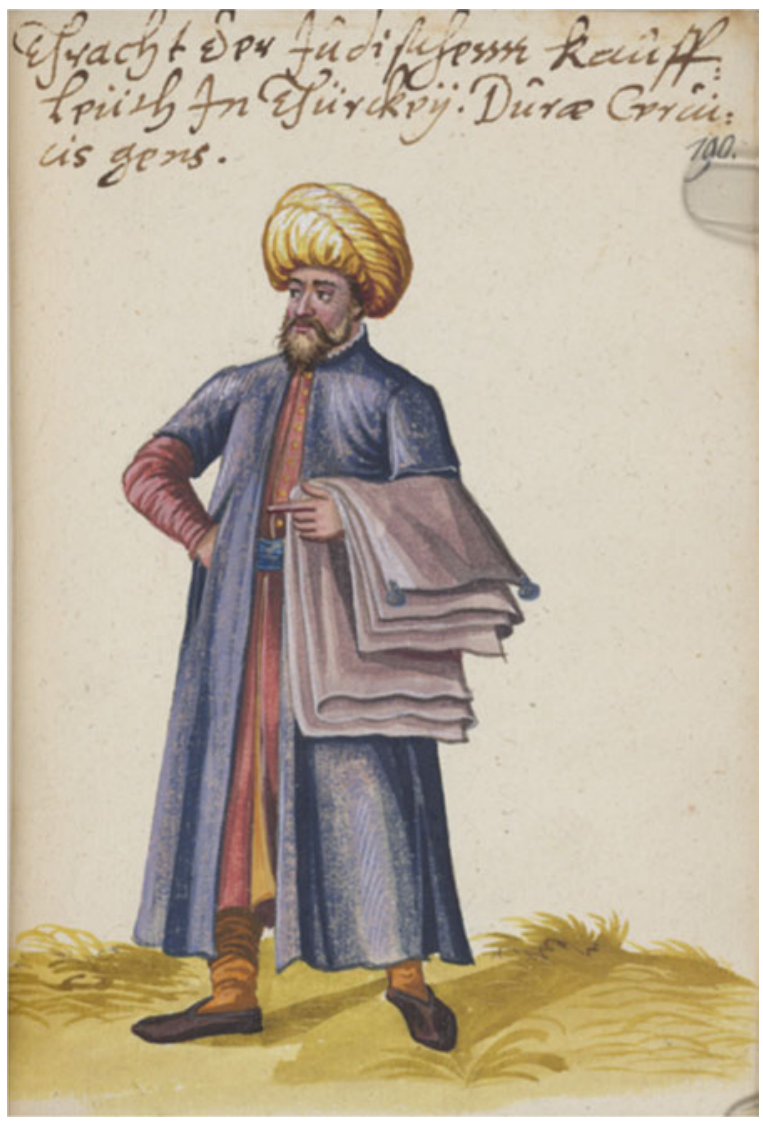

Fig. 1 1. Ottoman Jewish merchant copied from de Bruyn, zum Lamm, Thesaurus Picturarum, xv, fo. 19or. (C) ULB Darmstadt

this outlandish character, 'a Phrygian, I believe', came the response. ${ }^{83}$ This confusion stemmed from a connection between the two lands in canonical works of the classically inspired, medieval histories describing the origins of Europe. Guido de Collone's famous account of the fall of Troy, Historia destructionis Troiae (c. 1287), describes Paris rushing into battle and killing the Frisian king in the presence of Ulysses. ${ }^{8} 4$ Guido's text was almost wholly derived from an earlier work (De excidio Troiae historia), by an author calling himself Dares Phrygius (named after the character Homer describes as a Trojan priest of Hephaestus) who was believed by the scholastics to have personally

83 P. S. Allen, The age of Erasmus: lectures delivered in the universities of Oxford and London by P. S. Allen (Percy Stafford), I869-1933 (Oxford, 1914), p. 18.

84 Guido de Colonne, Historia destructionis Troiae, ed. Nathaniel Edward Griffin (Cambridge, MA, 1936), p. 142 . 


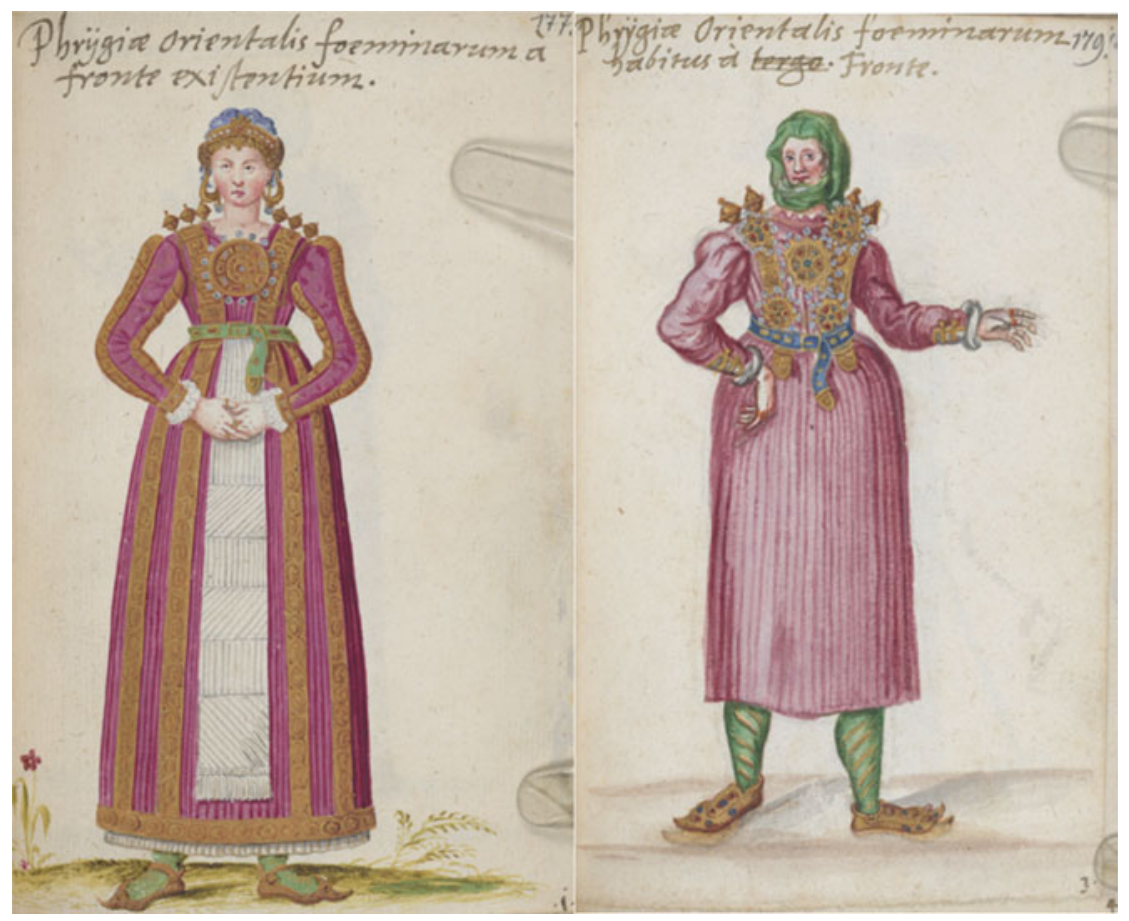

Fig. 12. The dress of 'Phrygian' women copied from Reformed East Frisian chieftain Unico Manninga's Hausbuch, zum Lamm, Thesaurus Picturarum, xv, fos. 177r, 179r. (C) ULB Darmstadt

witnessed the fall of Troy. In truth, the pseudo-Dares was a sixth-century scholar of 'Frankish' origin. By the high middle ages, the myth that the Franks were the descendants of Trojans fleeing Asia Minor had become commonplace. First called Frisii by Tacitus, and also by Pliny, a nominal and historical-mythological connection between the peoples of Phrygia (or Troy) and Frisia became tenable in the eyes of scholastics resolved by the 'literal sense of the word'; especially given the early association between Frisians and the Franks after their subjugation by Charlemagne, the result - over a longue durée - of conflated origin myths in circulation since the fall of Rome. ${ }^{8} 5$ Belief in this ancient connection was well established by the high middle ages, and remained entangled with histories of Germany and Europe during the time of zum Lamm. A text on the reverse of a map of Frisia, published in 1595 by the Dutch cartographer Abraham Ortelius, reads 'Whether the inhabitants of this place are indigenous, or whether they originate and derive their appellation from the Phrygians of Asia, as some would have it...I leave for the learned to decide.' ${ }^{86}$ Indeed, the East Frisians had a

\footnotetext{
85 Frederic Clark, 'Authenticity, antiquity, and authority: Dares Phrygius in early modern Europe', Journal of the History of Ideas, 72 (2011), pp. 183-207.

86 Abraham Ortelius, Theatrum orbis terrarum (Antwerp, 1595), p. 45.
} 
curious history of independence from the empire, retaining a pre-feudal system of chieftains and an unindentured peasantry who had escaped the yoke of serfdom. ${ }^{8} 7$

Whilst Phrygians and Frisians now had different names, the essence of these cultures, connected by the myth of an ancient migration, were one and the same, and this could be observed. Disclosed by the history of either peoples' dress, zum Lamm observes the essence of a shared culture and identity. He believes that a set of mutual characteristics remain innate within these ostensibly distinct groups. By accurately reproducing the visual forms of East Frisian people, the viewer is also presented with the forms of Phrygians.

When considered in relation to zum Lamm's image of Germanness in Costumes (vol. xxiII) and Additions (vol. xxxIII), the Frisian-Phrygian images help illustrate the boundary of an imaginary, ethno-geography described by the appearances of dress and linked to an enduring German scholarly interest in the movements of ancient peoples. By not including Manninga's images of East Frisians amongst his German pictures, choosing, rather, to label them as Phrygians, he condemns those people, along with their idiosyncratic histories of freedom and dress, to alterity. For zum Lamm, despite linguistic and geographical proximity, the East Frisians appear foreign enough that they might feasibly dwell among the foothills of Anatolia.

Three years after zum Lamm's death, in 16og, the Cologne Calvinist, refugee, and cartographer Matthias Quad dedicated his Teutscher Nation Herrligkeit to Count Palatine Friedrich V (whose failed pursuit of the Bohemian crown in 1619 would result in the beginning of the Thirty Years War). ${ }^{88}$ Whilst excluding East Frisia from his description of Germany, he writes in his entry on West Frisia, 'As far as the name Frisie is concerned [Suffridus Petrus] does not want to believe that the Frisians should have come from Troy, that the Phrysii were as much as Phrygii, rather that they retain their name from their founder, Friso.' 89 Opening with a short history of the German nation, Quad's vision of Germany was considerably more inclusive than Freher's and zum Lamm's before him, stretching over the Netherlands in the west, Switzerland in the south, Bohemia and Prussia in the east. Parenthesizing his topographical-historical delineation of German lands, he describes German mining and mineral deposits, inventions, indigenous illnesses and their cures, spa towns, and the greatest German artists and intellectuals of the 'last two-hundred years'.90 History, climate, landscape, natural philosophy, customs, and costume revealed the national character and united Germany's diverse regions. Addressing his work to the head of the newly formed Protestant Union, Quad's political

87 David M. Luebke, 'Of liberty and the Upstalsboom: urban-rural alliances and symbols of freedom in early modern East Frisia', in Michael Printy et al., eds., Politics and reformations: communities, polities, nations, and empires (Leiden, 2007), pp. 259-82.

88 Schmidt, Vaterlandsliebe, p. 191.

89 Matthias Quad, Teutscher Nation Herrligkeit... (Cologne, 16o9), p. 338.

9o Ibid., pp. 393-46o. 
motives were to present an irenic, united vision of the German Reich which in reality was on the eve of war. He describes an idealized German nation, and the Reich as a functioning state with a seamlessly ordered hierarchy of spiritual and secular princes. The Count Palatine is presented as the premier German prince, holding suzerainty over the Rhine-Danube heartland ('the Rhenish, Swabian, and Franconian territories') by ancient right, and the final say over the election of a new emperor.$^{11}$ Once again, the idea-image of Germany, ever malleable, is guided by the moment's political mise-en-scéne. Whilst zum Lamm's and Freher's exclusive visions of Germany, reduced to the Rhine-Danube heartland, accord with the relative stability of confessional order and the particularities of Palatine dynastic and confessional ambitions in the late sixteenth century, Quad's inclusive vision is acclimatized to changing Palatine and imperial German political scenarios, preluding the outbreak of the Thirty Years War.

\section{V}

Beginning with a genealogy of the variegated imaginings and visualizations of Germanness over the sixteenth century, this article has argued that the costume images compiled in Marcus zum Lamm's Thesaurus Picturarum must be read within a wide framework of sixteenth-century knowledge practices and patriotic projects. His German costume studies are related to topographical-historical, cartographic, ethnographic, natural philosophical, and genealogical genre traditions; the intellectual products of convergent scholarly and artisanal epistemologies, interests, and networks. His precise vision of Germany reflects the German theatre of Palatine territorial and confessional ambitions-bounded within the 'ancient' Rhine-Danube heartland-and must also be read alongside a number of other costume collections inter-textually. Among these, works such as Hans Weigel's Trachtenbuch would have influenced a proto-nationalistic and moralistic reading of his collection.

Confessionalization created a cosmopolitan centre of European Calvinism in Heidelberg, and this complemented zum Lamm's 'global' approach to costume, which, at the same time, consolidated his image of Germanness visá-vis that of alterity. His interests in eschatology, meteorology, wondersigns, and astrology help us define zum Lamm's political understanding of competing 'greater' and 'lesser' Germanies, as well as the context within which he constructed an apocalyptic picture of Islam. However, this does not preclude a sincere ethnographic interest in degrees of human difference, near and far. By including pictures of 'Jews in Worms' among his German images, and by allocating East Frisians as Phrygians in his Turcica volume, zum Lamm reveals how the subjective appropriation of a 'visual epistemology' (evident also in his ornithological images) could guide the learned eye toward unearthing 'hidden' qualities. In this case, the Rhineland Jews' connections to German topography,

$9^{1}$ Ibid., pp. 19-20. 
economy, and history, and the Frisians' ontological un-Germanness, their exotic dress revealing the 'truth' of their Phrygian origins, explained textually with reference to classical authority.

Working within a broader scholarly framework than most scholarship on German costume images has attempted to date, this article has shown how zum Lamm's costume collection illuminates a complex narrative of continuity and change in how the idea-image of Germany was constructed visually over the sixteenth century. Whilst the works of humanist and classical authorities continued to provide the normative apparatuses with which to construct Germanness, each reimagining would be influenced by the precise confessional, territorial, and political contexts of its production. Although we can view zum Lamm's collection as an early attempt at visual, comparative ethnography, facilitated by cosmopolitan, trans-territorial networks of artisan-artists, scholars, and material exchange, it is also one formed by the proto-nationalist voice and vision of Palatine dynastic and confessional ambitions; precedent and contemporary German patriotic topographical-histories, costume books, and manuscript alba; as well as the didacticism which so often flavoured the intellectual outputs of sixteenth-century Europeans. 